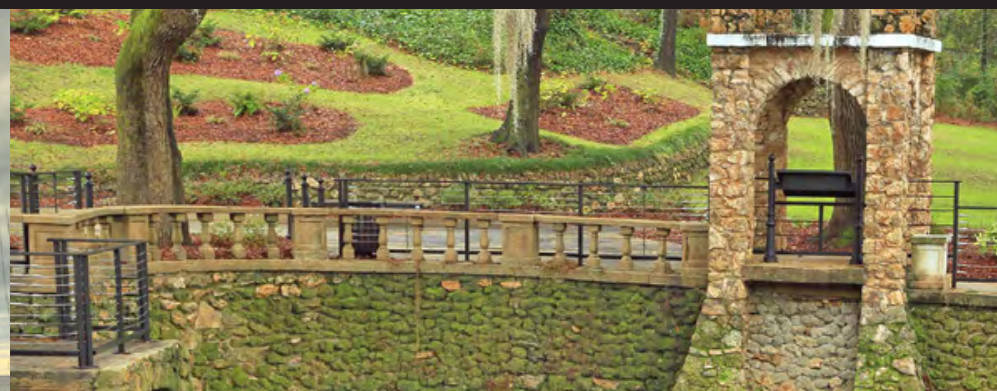

\title{
South Atlantic Water Science Center Strategic Science Plan:
} 2019-23

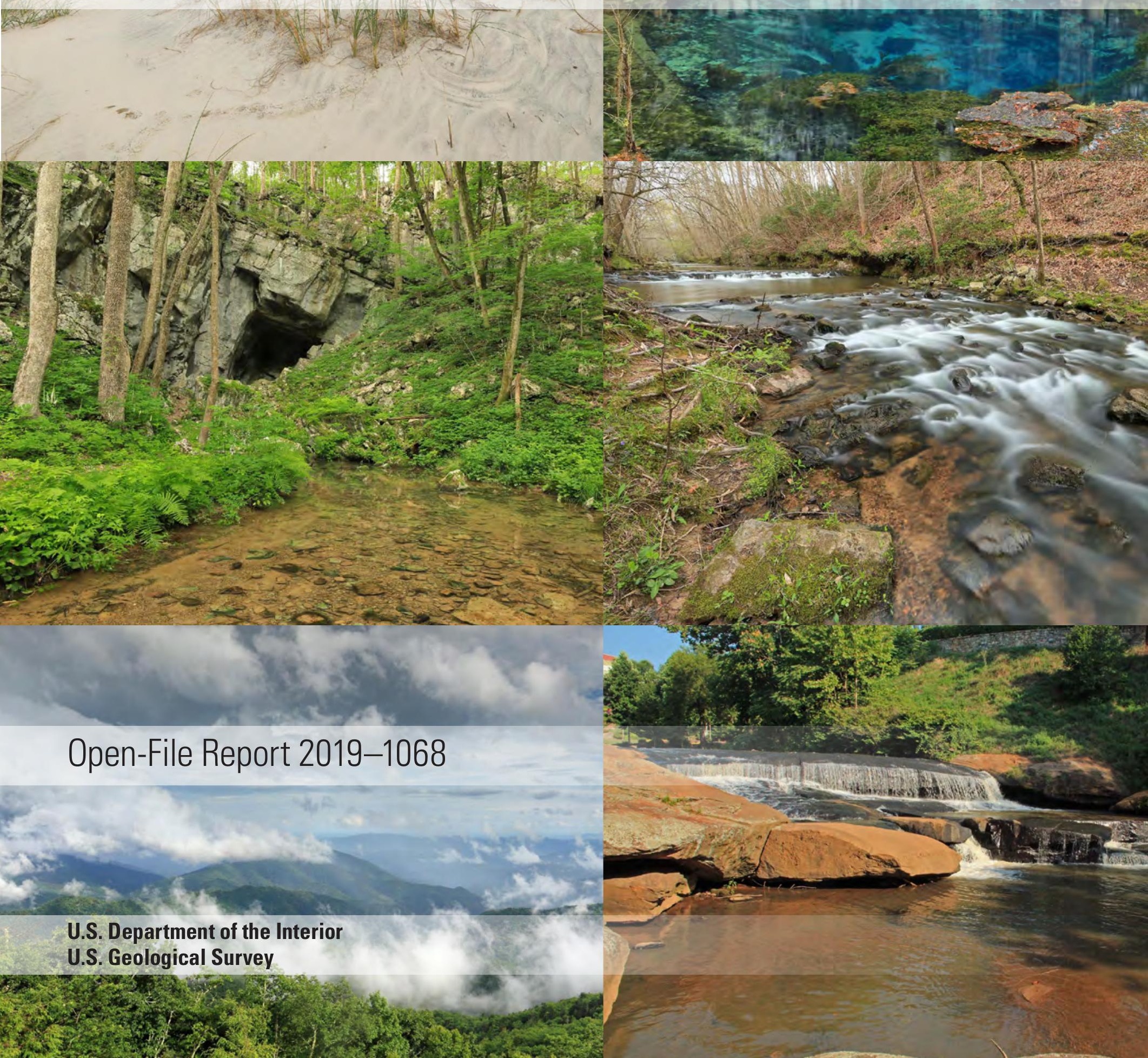


Coastal Plain, Jekyll Island, Glynn County, Georgia

Appalachian Plateaus, Lookout Mountain, Walker County, Georgia

Blue Ridge Province, Laurel Knob Overlook, McDowell County, North Carolina
Coastal Plain, Radium Springs, Dougherty County, Georgia

Valley and Ridge Province, Chattahoochee National Forest, Floyd County, Georgia

Piedmont Province, Lower Reedy River Falls, Greenville County, South Carolina 


\section{South Atlantic Water Science Center Strategic Science Plan: 2019-23}

By Thomas F. Cuffney, Ana M. Garcia, Arthur J. Horowitz, Jacob H. LaFontaine, James E. Landmeyer, Anna M. McKee, Kristen Bukowski McSwain, Jaime A. Painter, John M. Shelton, and Christopher A. Smith

Open-File Report 2019-1068 


\title{
U.S. Department of the Interior DAVID BERNHARDT, Secretary
}

\author{
U.S. Geological Survey \\ James F. Reilly II, Director
}

U.S. Geological Survey, Reston, Virginia: 2019

For more information on the USGS - the Federal source for science about the Earth, its natural and living resources, natural hazards, and the environment-visit https://www.usgs.gov or call 1-888-ASK-USGS (1-888-275-8747).

For an overview of USGS information products, including maps, imagery, and publications, visit https://store.usgs.gov.

Any use of trade, firm, or product names is for descriptive purposes only and does not imply endorsement by the U.S. Government.

Although this information product, for the most part, is in the public domain, it also may contain copyrighted materials as noted in the text. Permission to reproduce copyrighted items must be secured from the copyright owner.

Suggested citation:

Cuffney, T.F., Garcia, A.M., Horowitz, A.J., LaFontaine, J.H., Landmeyer, J.E., McKee, A.M., McSwain, K.B., Painter, J.A., Shelton, J.M., and Smith, C.A., 2019, South Atlantic Water Science Center strategic science plan-2019-23: U.S. Geological Survey Open-File Report 2019-1068, 31 p., https://doi.org/10.3133/ofr20191068.

ISSN 2331-1258 (online) 


\section{Contents}

Executive Summary .........................................................................................................................

Mission Statement

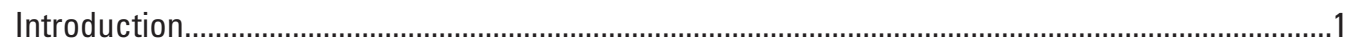

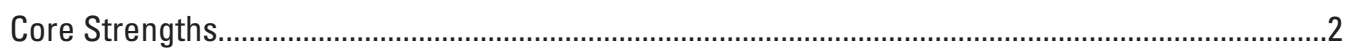

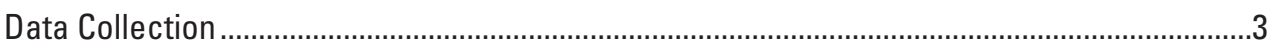

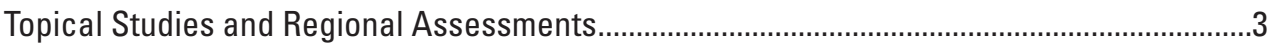

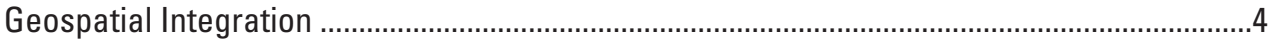

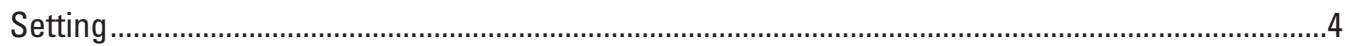

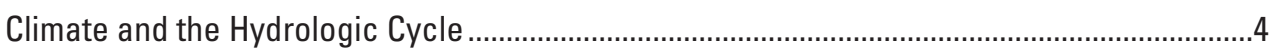

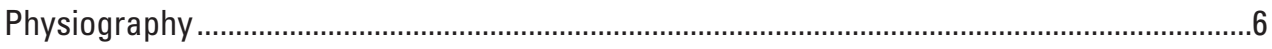

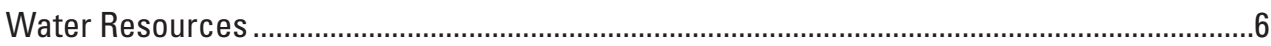

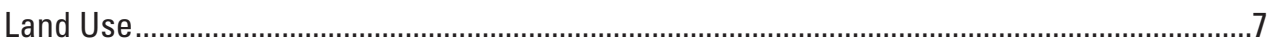

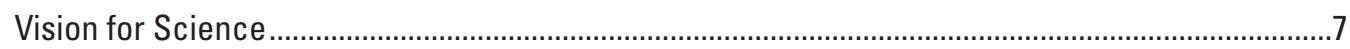

Priority Science Topics and Associated Science Goals ..................................................................

Topic 1: Foundational Data ..............................................................................................

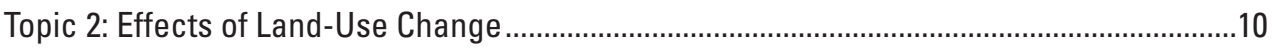

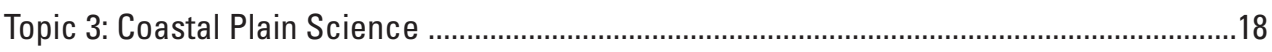

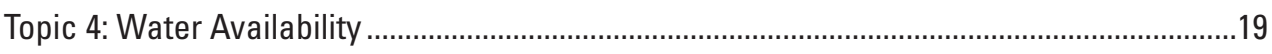

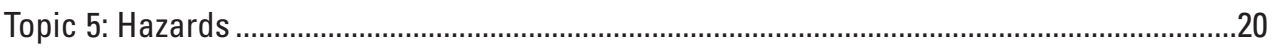

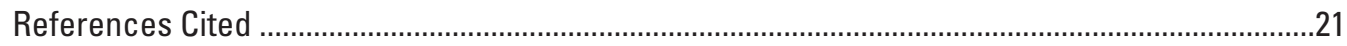

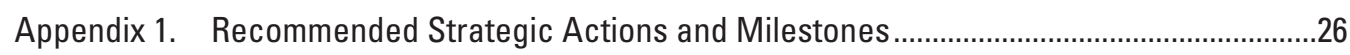

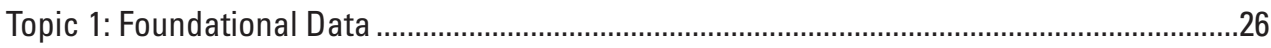

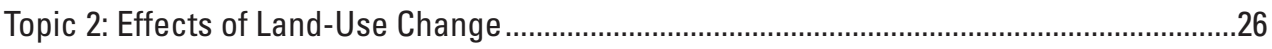

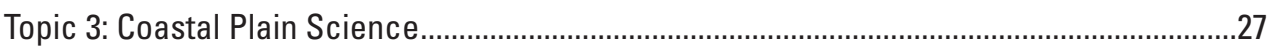

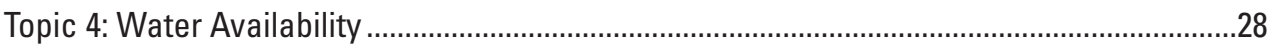



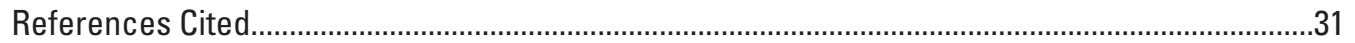

\section{Figures}

1. Map showing South Atlantic Water Science Center locations and physiographic provinces in the South Atlantic region ...................................................

2. Photograph of South Atlantic Water Science Center staff collecting samples for environmental DNA research .................................................................

3. Photographs of representative landscapes of the physiographic provinces in the South Atlantic region: Coastal Plain, Jekyll Island, Glynn County, Georgia, 2016; Coastal Plain, Radium Springs, Dougherty County, Georgia, 2015; Appalachian Plateaus, Lookout Mountain, Walker County, Georgia, 2017; Valley and Ridge Province, Chattahoochee National Forest, Floyd County, Georgia, 2016; Blue Ridge Province, Laurel Knob Overlook, McDowell County, North Carolina, 2015; Piedmont Province, Lower Reedy River Falls, Greenville County, South Carolina, 2012

4. Map showing 6-digit hydrologic unit code watersheds in the South Atlantic region. 
5. Map showing population density by county in the South Atlantic region

6. Map showing the South Atlantic Water Science Center's 2017 network of groundwater, surface-water, and water-quality monitoring sites.

7. A-E, Maps showing historical and projected land use in the South Atlantic region

8. Maps showing the change in irrigated acres from 2002-2007 and 2007-12

9. Diagram showing natural and anthropogenic interactions in the hydrologic cycle.

10. Map showing streamgage sites in the South Atlantic region where the U.S. Geological Survey has created flood-inundation maps.

\section{Table}

1. Historical and projected future land-use percentages in the South

Atlantic region.

\section{Conversion Factors}

\begin{tabular}{lcl}
\multicolumn{1}{l}{ U.S. customary units to International System of Units } & \multicolumn{1}{c}{ To obtain } \\
\hline & \multicolumn{1}{c}{ Multiply } & By \\
\hline inch (in.) & Length & \\
foot (ft) & 2.54 & centimeter $(\mathrm{cm})$ \\
mile (mi) & 0.3048 & meter $(\mathrm{m})$ \\
\hline & 1.609 & kilometer $(\mathrm{km})$ \\
\hline acre & Area & \\
\hline square meter $\left(\mathrm{m}^{2}\right)$ & 4,047 & square meter $\left(\mathrm{m}^{2}\right)$ \\
\hline
\end{tabular}

\section{Abbreviations}

ET

GIS

HABs

HUC

lidar

NASA

SAWSC

SPARROW

SSP

UAS

USGS evapotranspiration

geographic information system

harmful algal blooms

hydrologic unit code

light detection and ranging

National Aeronautics and Space Administration

South Atlantic Water Science Center

SPAtially Referenced Regressions On Watershed attributes

strategic science plan

unmanned aircraft system

U.S. Geological Survey 


\section{Executive Summary}

The South Atlantic Water Science Center Strategic Science Planning Team has developed a unified strategic science plan to guide the science vision of the South Atlantic Water Science Center (SAWSC) in response to the merging of the Georgia, North Carolina, and South Carolina Water Science Centers. This plan proposes a path forward to keep SAWSC science activities relevant to the many diverse needs of stakeholders in the South Atlantic region (Georgia, North Carolina, and South Carolina) and considers the hydrologic setting and issues of the region. This plan advises the creation of five working groups to address five priority science topics for the period 2019-23 and beyond. The five priority science topics are (1) Foundational Data, (2) Effects of Land-Use Change, (3) Coastal Plain Science, (4) Water Availability, and (5) Hazards. From the goals laid forth in this plan for each priority science topic, the working groups plan to devise a set of strategic actions and milestones to be achieved by the SAWSC to provide valuable and relevant data, research, and assessments in the South Atlantic region. In this report, the "South Atlantic region" is used to describe the area encompassed by the States of North Carolina, South Carolina, and Georgia. 


\title{
South Atlantic Water Science Center Strategic Science Plan: 2019-23
}

\author{
By Thomas F. Cuffney, Ana M. Garcia, Arthur J. Horowitz, Jacob H. LaFontaine, James E. Landmeyer, \\ Anna M. McKee, Kristen Bukowski McSwain, Jaime A. Painter, John M. Shelton, and Christopher A. Smith
}

\section{Mission Statement}

The mission of the U.S. Geological Survey (USGS) South Atlantic Water Science Center (SAWSC) is to lead the scientific characterization of groundwater and surfacewater resources and their interactions with earth processes and human activities in Georgia, North Carolina, and South Carolina, herein referred to as the South Atlantic region (fig. 1). This mission is met through reliable data collection and monitoring, impartial assessment and research, and timely publication and dissemination of informational products. The SAWSC provides data, research, and information that can be used to manage the interactions between humans and the environment, as well as predict and mitigate the effects of natural and anthropogenic hazards in the Southeastern United States and potentially other regions.

\section{Introduction}

The USGS has a long-standing reputation of national leadership as the Department of the Interior's lead science bureau, providing information and research related to natural resources and natural hazards (National Research Council, 2007). The primary responsibilities of the USGS are to collect, map, develop, archive, and provide continuous, reliable data and cohesive information about the Nation's hydrological, geological, and biological resources. Among Federal natural-resource agencies, the USGS is unique in its ability to provide objective and unbiased science because it has no regulatory function or advocacy role. The USGS develops interdisciplinary earth-science programs that have regional, national, and global perspectives. The ability of the USGS to integrate geological, hydrological, geographical, and biological capabilities provides unparalleled opportunities to translate science into accessible information. This document outlines the SAWSC strategic science plan (SSP), which supports the overall USGS mission in its commitment to supplying unbiased, high-quality data and science to support local, regional, and national priorities.
The SAWSC was established on October 1, 2014, when the North Carolina, South Carolina, and Georgia Water Science Centers were combined into a single center. Creating a multistate Water Science Center provides new opportunities and challenges for managers, scientists, and technicians as they work together to address multistate water-science issues and contend with stakeholder priorities that often differ among States. Combining the three Centers provides an opportunity to assess our science priorities in light of the water-science needs of a region that contains more than 25 million people, 100,000 stream miles, 8,500 miles of Atlantic Ocean shoreline (National Oceanic and Atmospheric Administration, undated), and 17.5 million acres of harvested cropland (U.S. Department of Agriculture, 2017) and consists of diverse physiographic provinces representing coastal to mountainous terrains (U.S. Geological Survey, 2017b). The geography, climate, population, and commerce within the South Atlantic region create many technical and scientific challenges that must be met to assess the status of ground- and surface-water resources and provide resource managers with the high-quality science needed to effectively manage these resources to support the water needs of humans and ecosystems.

The South Atlantic Water Science Center Strategic Science Planning Team determined five priority scientific topics for the SAWSC and identified goals to address each priority science topic over the next 5 years. This SSP was developed by a 10 -member science planning team composed of members nominated by their peers and selected by SAWSC senior managers to represent the geographic and technical diversity of the Center. In the development of this plan, the science planning team solicited input from SAWSC staff, USGS technical experts and senior leaders, and cooperators. This SSP is intended to focus and direct the capabilities of science provided to local and State governments, other Federal agencies, and the public of North Carolina, South Carolina, and Georgia. This plan was developed by evaluating the societal relevance of individual projects and by planning for future activities through program development, hiring, training, and the development of relevant analytical capabilities. Successful execution of the SAWSC SSP requires interdisciplinary and integrated approaches; a long-term commitment to 


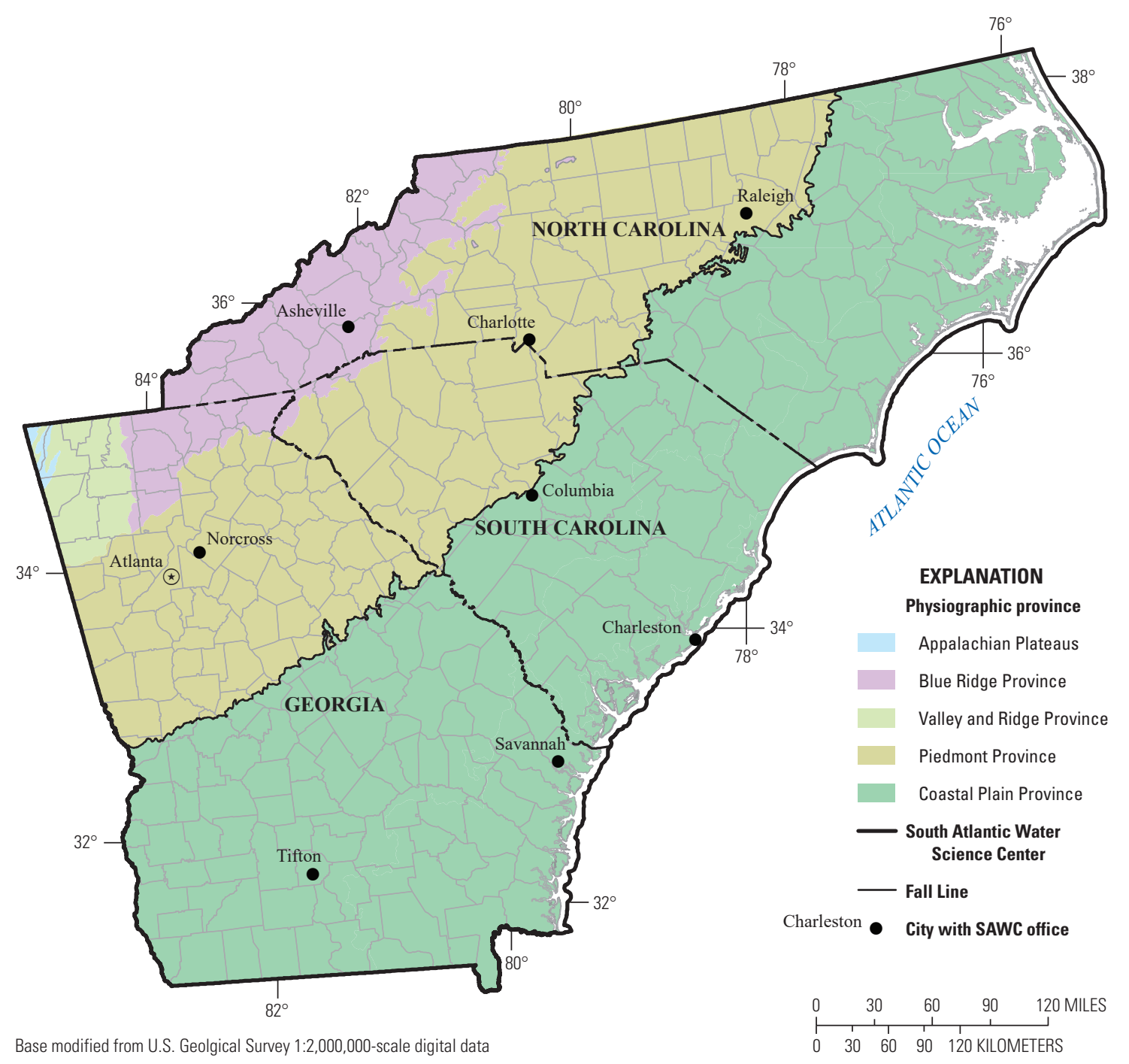

Figure 1. Map showing South Atlantic Water Science Center (SAWSC) locations and physiographic provinces in the South Atlantic region (North Carolina, South Carolina, and Georgia). Physiographic provinces are from Fenneman and Johnson (1946).

high-quality, unbiased data collection, analysis, and research; and effective internal and external partnerships. This plan can be used by SAWSC and regional leaders to formulate, justify, and support both long-term and short-term water-resources programs; maintain institutional resolve to continue sustained support of monitoring and research; and enhance scientific opportunities by communicating our core strengths and presenting a clear and concise vision for addressing relevant scientific issues to elected officials, partners, other agencies, and the research community at large.

This plan fulfills the USGS Water Mission Area goals, which are to (1) provide society the information it needs regarding the amount and quality of water in all components of the water cycle at high temporal and spatial resolution, (2) advance understanding of processes that determine water availability, (3) predict changes in the quantity and quality of water resources in response to changing environmental and societal conditions, (4) anticipate and respond to water-related emergencies and conflicts, and (5) deliver timely hydrologic data, analyses, and decision-support tools seamlessly to support water-resource decisions (Evenson and others, 2013).

\section{Core Strengths}

For over 125 years, the USGS has provided the scientific foundation and perspective to evaluate and identify the status and trends of natural resources in the South Atlantic region (fig. 1). We strive to make our work broadly relevant to other locations and disciplines by collaborating with other agencies (Federal, State, and private), universities, municipalities, utilities, nongovernmental organizations, international organizations and agencies, and the public. 


\section{Data Collection}

We collect data using standardized methods and thorough quality-assurance/quality-control protocols to ensure accurate, reliable, and nationally compatible open-access data that are trusted and used by local municipalities, State and Federal agencies, nongovernmental organizations, and the public. The data are collected across the South Atlantic region as part of our Data Program. The Data Program consists of an extensive network of surface-water and groundwater monitoring gages, including near-real-time sites that facilitate rapid responses to changing conditions and long-term sites that enable trend analysis. We monitor in near real time physical and chemical properties of water, such as temperature, specific conductance, turbidity, dissolved-oxygen concentration, and nitrate concentration, as well as stream height and discharge. Our expertise in borehole and surface geophysics tools and karst hydrology provides a valuable resource for on-site monitoring of well development and characterization. Our data-collection innovations include the use of real-time river cameras for monitoring bank erosion, debris pileup, and changes in stream velocity and discharge; autonomous underwater vehicles that enable the collection of high-quality water-quality, velocity, and bathymetry data (Clark and others, 2014; Conrads and others, 2017; Conrads and others, 2018; Petkewich and others, 2018); and rapid deployment gages and storm-tide sensors to capture barometric pressure, wave height, water level, and meteorological data during tropical storms, hurricanes, and other flooding events (Feaster and others, 2018). The Data Program includes the largest urban hydrology program in the country.

\section{USGS Urban Hydrology Program in Metropolitan Atlanta, Georgia}

The USGS urban hydrology program provides continuous monitoring of streamflow, precipitation, and select water-quality data at over 60 urban streams around Metropolitan Atlanta. An example of the success of this program is the inclusion of a heavily urbanized watershed (Proctor Creek) as 1 of only 14 watersheds selected nationally for the Urban Waters Federal Partnership (https://www.epa.gov/urbanwaterspartners; https://www.epa.gov/urbanwaterspartners/ urban-waters-and-proctor-creek-watershedatlanta-georgia). The Partnership is a high-level effort to promote water conservation and the enhancement of the value and quality of water resources within highly urban areas.

\section{Topical Studies and Regional Assessments}

The SAWSC Studies Program has published research results on a wide variety of topics that affect the Southeastern United States (https://www.usgs.gov/centers/sa-water/science/ research-and-investigations?qt-science center_objects $=0 \# q$ qtscience_center_objects). Our research scope is extensiveefforts range from laboratory experiments that use radiolabeled tracers to track the bacterially mediated conversion of contaminants into innocuous byproducts to watershed-scale experiments in the Panola Mountain Research Watershed (https://www.usgs.gov/centers/sa-water/science/small-watershed-studies-panola-mountain-research-watershed-georgia?qtscience_center_objects $=0 \#$ qt-science_center_objects; part of the Water, Energy, and Biogeochemical Budgets program) that characterize hydrological and biogeochemical processes, and regional aquifer and watershed studies, such as the Regional Groundwater Availability Studies (https://water. usgs.gov/watercensus/groundwater.html) and the National Water Quality Assessment (https://water.usgs.gov/nawqa/), to provide background information on, and assess the status of, surface-water and groundwater resources in the South Atlantic region. We developed numerical models that are used to estimate current and predict future groundwater and surface-water availability and quality. This modeling expertise has been uniquely used to couple surface-water and groundwater dynamics into integrated models that address regional water-resource issues such as saltwater intrusion dynamics in groundwater in the Coastal Plain and agricultural water use. We developed models to estimate bacteria levels in the Chattahoochee River National Recreation Area in Metropolitan Atlanta, Georgia, to inform the public of the risk of exposure to bacterial contamination (called the BacteriAlert program; https://www2.usgs.gov/water/southatlantic/ga/ bacteria/index.php). At the national scale, we have used our analytical expertise in surface-water modeling to develop models of streamflow estimation for ungaged basins and delineation of small, upland streams. Regionally, we have developed expertise in SPARROW (SPAtially Referenced Regressions On Watershed attributes; https://water.usgs.gov/ nawqa/sparrow/) modeling to empirically estimate the origin and fate of contaminants in rivers. The Center also has developed expertise in the field of environmental DNA (eDNA) to assess species presence and biological community structure (fig. 2).

Many of our studies are cross-disciplinary, such as investigation of the following:

- The hydrologic factors affecting fate and transport of mercury in biological communities;

- The effects of nutrients on algal biomass and biological communities;

- The interaction between natural and engineered microbial communities to clean up contaminated groundwater; 


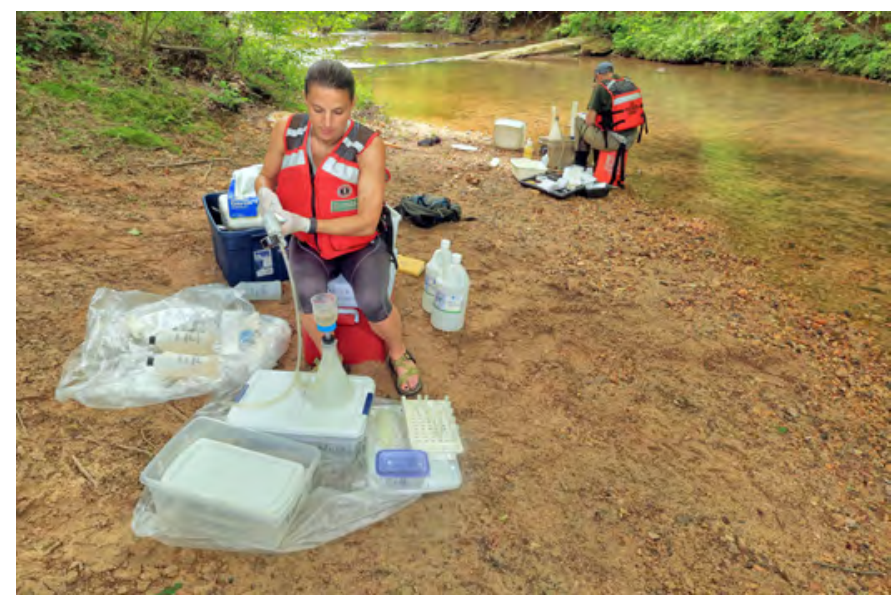

Figure 2. Photograph of South Atlantic Water Science Center (SAWSC) staff collecting samples for environmental DNA (eDNA) research. The SAWSC has been an integral contributor to foundational eDNA research with projects including the assessment of eDNA as a tool for detecting imperiled pondbreeding amphibians in the Southeastern United States and the comparison of community survey results between traditional fish and invertebrate sampling methods and eDNA sequencing. Photograph by Alan Cressler, U.S. Geological Survey.

- The uptake of contaminants by trees for phytoremediation of contaminated soils and groundwater;

- The detection and fate of a variety of contaminants of emerging concern; and

- The use of trees as naturally emplaced monitors of environmental contamination.

\section{Geospatial Integration}

Geospatial analyses turn data into information that can be used by stakeholders for decision making. Our hydrologic studies and data programs work closely with geospatial experts to create and provide stand-alone spatial products. Analyzing environmental data in a spatial context facilitates the understanding of how attributes are related and provides a framework for the visual investigation and statistical analysis of spatial correlation within the data. The SAWSC is recognized as a national leader in the development of highly accurate flood-inundation mapping geospatial products. As one of the first centers to have substantial light detection and ranging (lidar) elevation data, the SAWSC has developed expertise in assimilating USGS streamgage data, flood highwater marks, and National Weather Service flood-forecasting stations into geospatial products used by flood-plain managers and other stakeholders. The SAWSC has extensive experience in generating products from high-resolution lidar point-cloud elevation data, particularly hydrography, canopy height, and land-cover classification data. Bathymetric mapping tools and studies (Clark and others, 2014), geostatistical analyses for estimating agricultural water use and network analysis (Torak and Painter, 2011; Painter and others, 2015), the aggregation of spatial data for surface and groundwater models (Jones and others, 2017; LaFontaine and others, 2017), and the development of tools such as the StreamStats application (https://streamstats.usgs.gov/ss/) are all evidence of the SAWSC's leadership in incorporating data and analytical methods in a geospatial environment.

\section{Setting}

The characteristics of the physiographic provinces within the South Atlantic region provide context for water-resources science planning. The South Atlantic region's mild temperatures and abundant moisture contribute to a historically productive agricultural economy and support the region's growth as a business, technology, military, and manufacturing center. Clean and abundant water supplies are vital to the region's economic health, the physical health of its residents, and the health of aquatic life in its streams, rivers, lakes, and estuaries.

The South Atlantic region encompasses 145,264 square miles and several physiographic provinces: Coastal Plain, Piedmont Province, Blue Ridge Province, Valley and Ridge Province, and Appalachian Plateaus (figs. 1 and 3). Landsurface elevation ranges from sea level along the Atlantic Ocean coastline to 6,684 feet in western North Carolina (Mount Mitchell, the highest peak east of the Mississippi River). The Eastern Continental Divide runs through all three States of the South Atlantic region; rivers to the west drain into the Gulf of Mexico, and rivers to the east drain into the Atlantic Ocean.

\section{Climate and the Hydrologic Cycle}

The South Atlantic region has a humid subtropical to continental climate with four distinct seasons. Annual average precipitation for the region is approximately $48-50$ inches, with most precipitation falling in the summer (Southeast Regional Climate Center, 2017). Winter precipitation is predominantly from long-duration, low-intensity frontal systems, whereas spring and summer precipitation is predominantly from intense convective thunderstorms. Tropical cyclones are not uncommon, occur in the late summer and fall, and primarily affect coastal areas. Evapotranspiration (ET) makes up a substantial part of the water budget. The estimated percentage of precipitation lost to ET ranges between 50 and 69 percent throughout much of the region, except for the Blue Ridge Province where the fraction ranges between 30 and 59 percent (Sanford and Selnick, 2012). Although large amounts of snowfall can occur in areas with high elevation, runoff from snowmelt is not a large component of the region's water budget. 


\section{A}

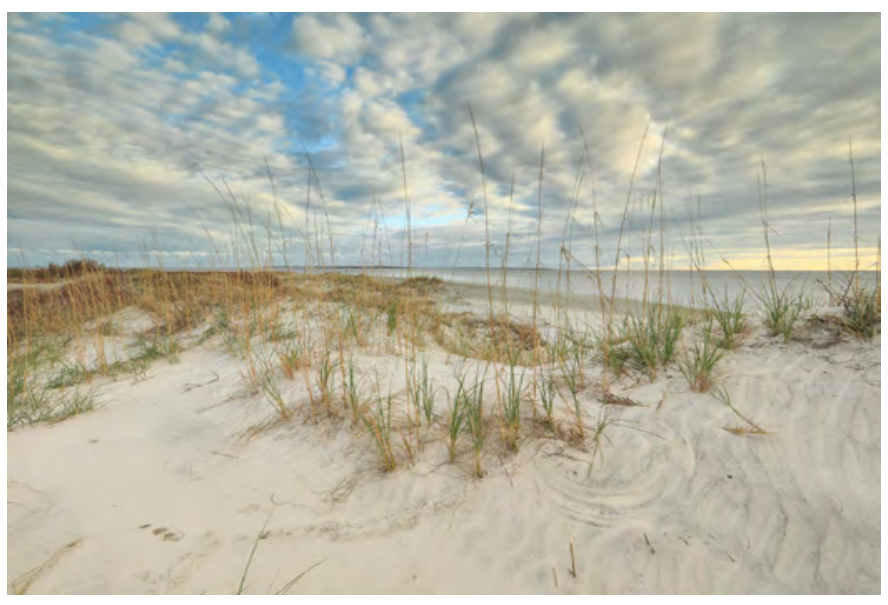

C

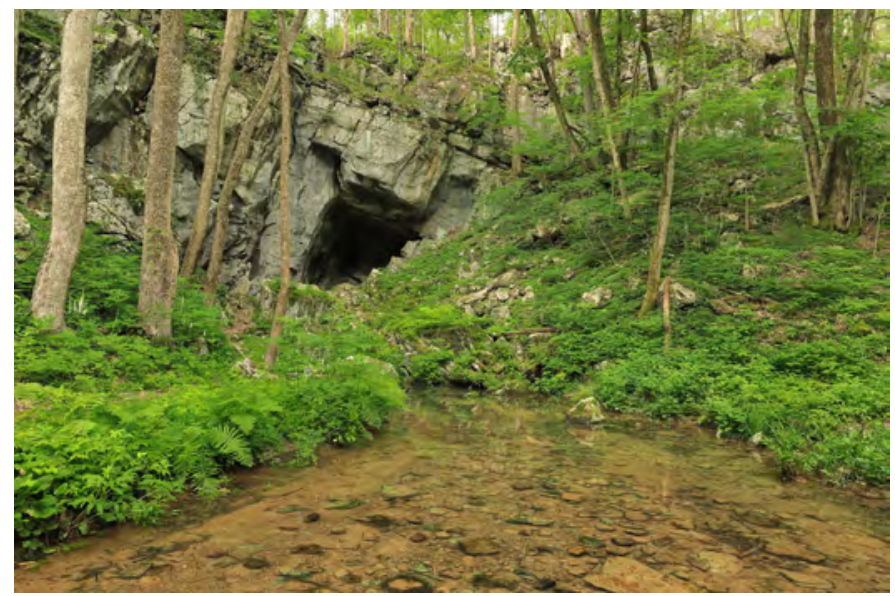

$\boldsymbol{E}$

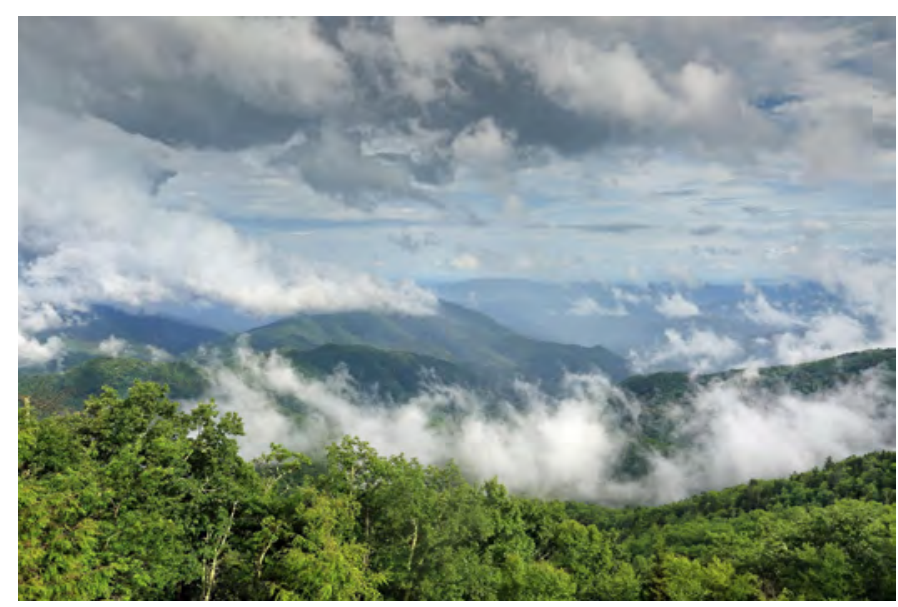

$B$

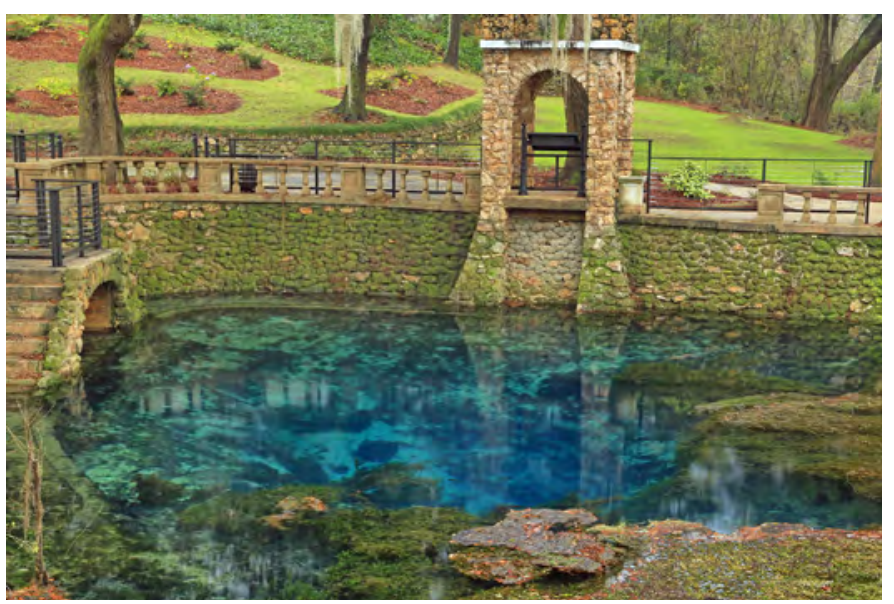

D

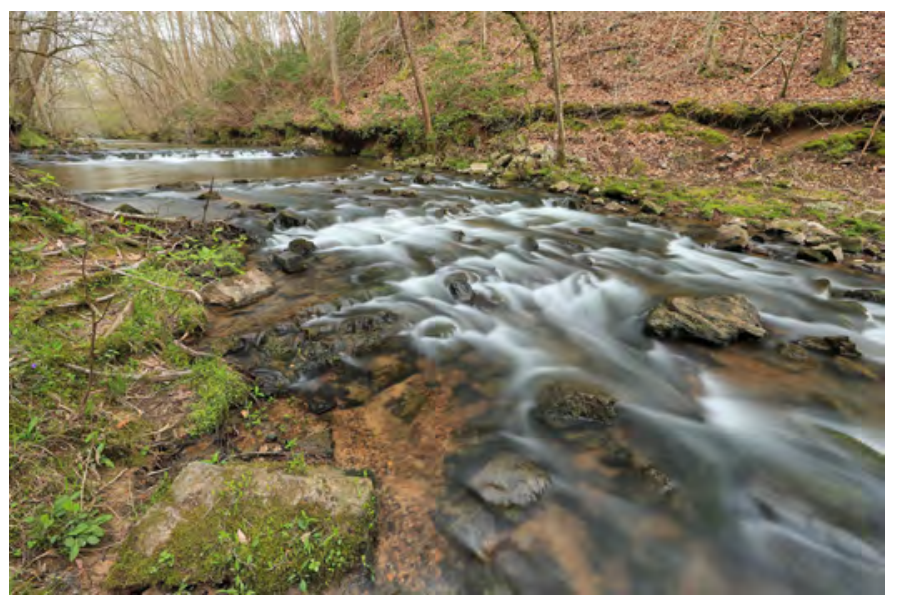

$\boldsymbol{F}$

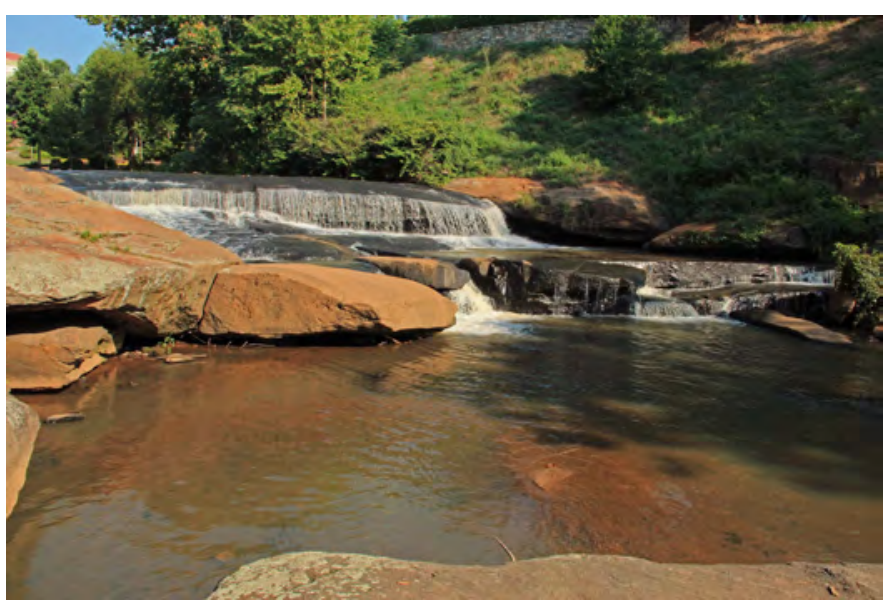

Figure 3. Photographs of representative landscapes of the physiographic provinces in the South Atlantic region: $(A)$ Coastal Plain, Jekyll Island, Glynn County, Georgia, 2016; (B) Coastal Plain, Radium Springs, Dougherty County, Georgia, 2015; (C) Appalachian Plateaus, Lookout Mountain, Walker County, Georgia, 2017; $(D)$ Valley and Ridge Province, Chattahoochee National Forest, Floyd County, Georgia, 2016; (E) Blue Ridge Province, Laurel Knob Overlook, McDowell County, North Carolina, 2015; (F) Piedmont Province, Lower Reedy River Falls, Greenville County, South Carolina, 2012. Photographs by Alan Cressler, U.S. Geological Survey. 
The seasonal variation of ET rates is the dominant control on the seasonality of the hydrologic cycle. Low rates of ET in the winter result in groundwater recharge and high stream base flows during the winter and early spring. High rates of ET during the summer result in losses from soil water and groundwater to ET and base flow, leading to low stream base flows in the summer and fall. Water-limiting conditions, when potential ET exceeds actual ET, can occur during the summer in some areas of the region and indicate a reduction in vegetative growth below its potential.

Flooding and drought are not uncommon in the region. Widespread flooding typically occurs during the late winter and early spring when base flows are high and in late summer and fall when tropical cyclones produce large amounts of precipitation. More localized flash floods can occur in the summer owing to intense convective thunderstorms. Despite its humid climate, the region has undergone recurring and often multiyear droughts that have threatened the sufficiency of water supplies. The region is particularly sensitive to droughts during the growing season because increases in irrigation for crops compete with other water-resource needs, including providing sufficient stream base flow for ecosystem services and aquatic organisms when base flow is already seasonally low.

\section{Physiography}

The South Atlantic region's physiographic provinces reflect distinct geologic settings. The more mountainous areas are the Blue Ridge Province, Valley and Ridge Province, and Appalachian Plateaus, whereas the Piedmont Province and Coastal Plain are relatively flat. The Piedmont and Blue Ridge Provinces are composed primarily of a complex of metamorphic, igneous, and metasedimentary rocks that have been exposed to intense heat and pressure related to mountain building and associated folding and faulting. As a result, these rocks typically have no substantial primary porosity, and most groundwater occurs in secondary fracture networks and in the overlying weathered regolith. In contrast, the Coastal Plain, Valley and Ridge Province, and Appalachian Plateaus are composed primarily of porous sedimentary rocks, including some solutional limestones that result in karst aquifers. The Valley and Ridge Province and Appalachian Plateaus are folded and erosionally dissected, precluding substantial regional aquifers. The Coastal Plain is composed of continuous layers of marine and terrestrial sediments and sedimentary rock that originated from the deposition of sediment eroding from the Appalachian Mountains to the west and from the Atlantic Ocean, which periodically submerged this area. These layers of porous sediments and rock of the Coastal Plain form a series of productive regional aquifers that store vast quantities of groundwater.

\section{Water Resources}

The South Atlantic region contains part or all of twenty-three 6-digit hydrologic unit code (HUC) watersheds (fig. 4). Runoff originating in Georgia, North Carolina, and South Carolina ultimately flows into the Atlantic Ocean or the Gulf of Mexico. Approximately 4.3 percent of the region's land cover is water (table 1). The Piedmont, Blue Ridge, Appalachian Plateaus, and Valley and Ridge Provinces have relatively large surface-water resources, whereas groundwater yield in these provinces varies locally depending on fracture density, secondary porosity, existence of solution cavities, geology, well depth, and water chemistry (Swain and others, 2004). The Coastal Plain has large and productive groundwater and surface-water systems.

Table 1. Historical and projected future land-use percentages in the South Atlantic region.

[Data are from Sohl and others (2014, 2016). The following categories from figure 7 have been consolidated: Deciduous, Evergreen, and Mixed are included under Forest; Grassland and Shrubland are included under Grass-shrub; Herbaceous wetland and Woody wetland are included under Wetland; and Clearcut (national forest), Clearcut (other public land), and Clearcut (private land) are included under Other]

\begin{tabular}{ccccccccccc}
\hline \multicolumn{1}{c}{ Year } & Urban & Water & Forest & Grass-shrub & Cropland & Hay-pasture & Wetland & Mining & Barren & Other \\
\hline 1940 & 1.4 & 3.2 & 45.6 & 0.0 & 27.8 & 6.7 & 15.2 & 0.0 & 0.1 & 0.0 \\
1970 & 3.0 & 4.0 & 53.2 & 0.0 & 20.3 & 6.7 & 12.6 & 0.1 & 0.1 & 0.0 \\
1990 & 3.9 & 4.3 & 56.6 & 0.1 & 15.6 & 7.0 & 12.3 & 0.1 & 0.1 & 0.0 \\
2020 & 7.0 & 4.4 & 51.7 & 0.1 & 15.6 & 6.2 & 12.1 & 0.2 & 0.1 & 2.6 \\
2050 & 10.5 & 4.4 & 44.3 & 0.1 & 19.5 & 5.9 & 11.9 & 0.2 & 0.1 & 3.1 \\
\hline
\end{tabular}




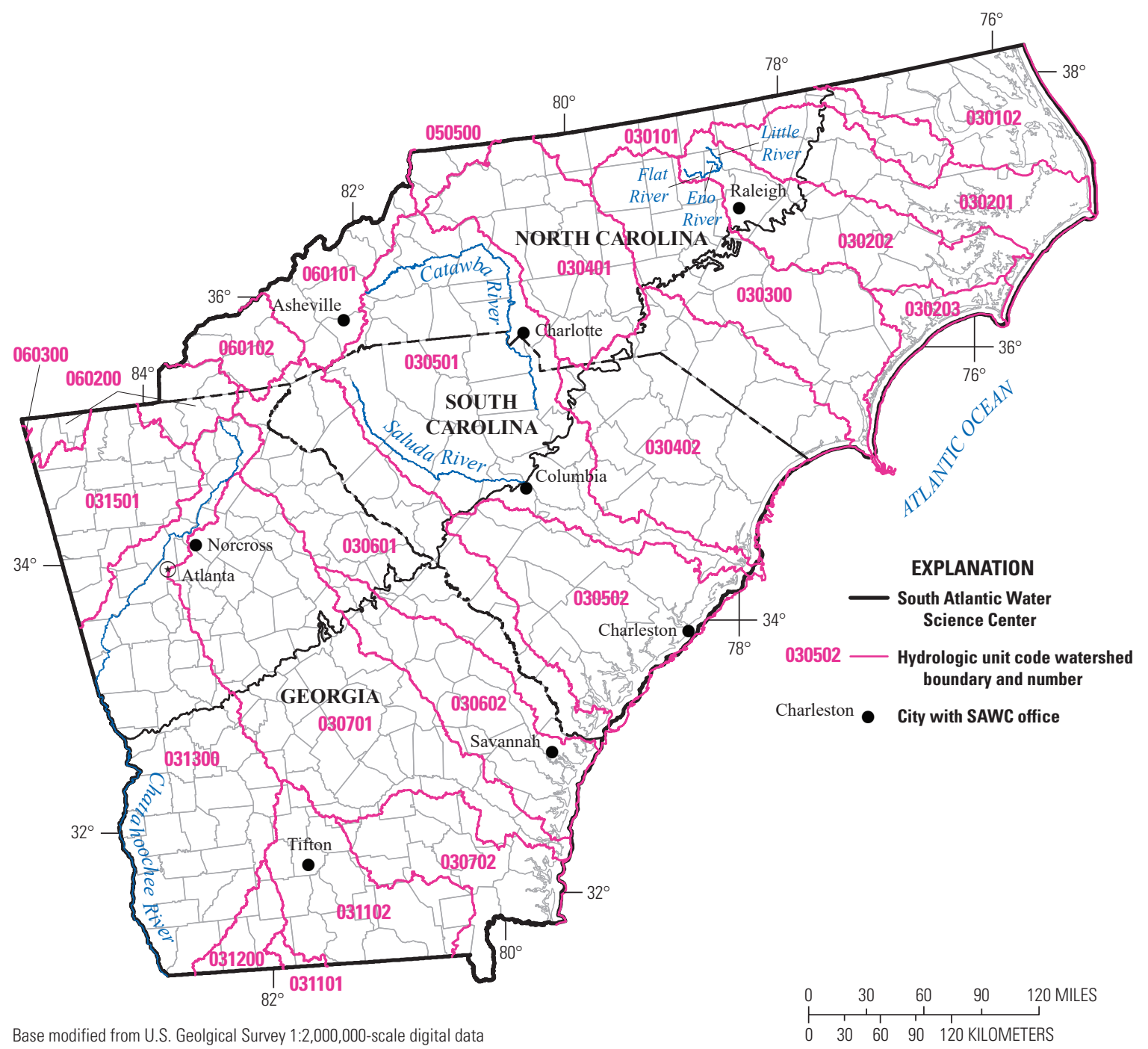

Figure 4. Map showing 6-digit hydrologic unit code (HUC) watersheds in the South Atlantic region. Dark blue rivers are mentioned in the text as water-supply sources for major metropolitan areas in the region. SAWSC, South Atlantic Water Science Center.

\section{Land Use}

The population in the South Atlantic region increased nearly 25 percent from approximately 20 million to 25 million between 2000 and 2015. Most of the population is concentrated in the area between Atlanta, Ga., Columbia, South Carolina, and Raleigh, North Carolina (fig. 5). The water supply for this metropolitan corridor comes primarily from surface water, with the Chattahoochee River providing much of the drinking water for Metropolitan Atlanta; the Catawba River for Metropolitan Charlotte, N.C.; the Saluda River for Metropolitan Columbia, S.C.; and the Eno, Little, and Flat Rivers for Metropolitan Raleigh (fig. 4). The coastal area, which forms a secondary corridor of dense population in the South Atlantic region, receives most of its potable water from groundwater sources. Agriculture is a major economic industry in the South Atlantic region, accounting for nearly $\$ 25$ billion of the South Atlantic regional economy in 2012. Irrigation water demand competes with increasing public water demand, both of which compete with ecosystems that are reliant on water resources. It is this reliance on and competition for limited water resources that shape the focal areas of our SSP.

\section{Vision for Science}

The SAWSC is committed to providing reliable hydrologic (groundwater and surface water) and water-related ecological information to aid in the understanding of hydrologic processes and the use and management of water resources in the South Atlantic region and the Nation at large. Through strong partnerships with our cooperators, stakeholders, and national programs, we strive to be a leader in the water-resources community. Through the integration of proven techniques with innovative 
methods and cutting-edge science, the SAWSC strives to advance water-related science.

The SAWSC SSP is built around five priority science topics:

1. Foundational Data-Collecting high-quality, on-demand, and interactive surface-water, groundwater, and waterquality data.

2. Effects of Land-Use Change-Examining how anthropogenic and natural changes to the landscape affect water resources.

3. Coastal Plain Science-Evaluating the state of coastal water resources.

4. Water Availability — Analyzing the quantity and quality of water available to meet human and ecological needs now and in the future.

5. Hazards-Assessing the effects of floods, droughts, hurricanes, and other water-resource-related hazards.

For each priority science topic, the SAWSC is committed to providing high-quality and comprehensive data collection, decision-support assessments for both long-term analysis and rapid response to emergencies, and scientific investigations that address the fundamental processes governing the quantity and quality of the water resources in the South Atlantic region and their effects on humans and ecosystems. We strive to proactively engage the public and science community with our science through social media and other outlets, such as fact sheets, storyboards, short videos, and press releases.

The Center is establishing Priority Science Topic Working Groups that are integral to the implementation of the SSP. The Priority Science Topic Working Groups will be charged with, but are not limited to, the following tasks: (1) review and refine the science goals and strategic actions and establish milestones for each science topic (see appendix 1); (2) keep abreast of recently approved proposals in the USGS National Proposal Repository that may be pertinent to cooperators of the SAWSC; (3) compile lists of relevant funding opportunities and new research projects or programs; (4) through communication with the science community, brainstorm ways to use innovative methodologies and technology to meet the goals of the science topic; and (5) develop broad-scale, interdisciplinary proposal ideas and identify and communicate with potential cooperators. The working group participants are planned to be USGS personnel that have the appropriate expertise and technical skills to meet the needs for each science topic.

In addition to the Priority Science Topic Working Groups, the implementation of the SSP is planned to occur through several SAWSC-wide actions:

- Annual face-to-face science conferences to evaluate the SAWSC's execution of the SSP and give scientists an opportunity to share their work, foster Centerwide collaboration, and provide input to the Priority Science Topic Working Groups about new science opportunities and ventures.
- Quarterly all-hands briefings hosted by the SAWSC Director, with opportunities for management to discuss current SAWSC activities with staff.

- Brown Bag Seminar Series, which can include administrative-, facility-, personnel-, or informationtechnology-focused developments, with recordings made available for those personnel who are not able to attend. We strive to foster the professional development of SAWSC staff to meet the USGS mission and determine a core set of curricula and specialized training.

Communication of the SAWSC's science is a key component of the SSP. Internal communication within the SAWSC is important, but external communication to the public is vital to the continued success of the SAWSC science plan. The Center should take the necessary steps to establish sophisticated outlets for dissemination. Specifically, the Center is focusing on methods to provide information to stakeholders and the public using social media, public outreach, and media opportunities. This action may not be explicitly listed as a strategic action for each priority science topic but is understood to be an integral part of each topic.

Implementation of the SSP necessitates a common culture among SAWSC offices that fosters interaction and collaboration among scientists, hydrographers, and managers, as well as the broader science community, including universities, Federal and State governmental agencies, municipalities, utilities, nongovernmental organizations, international organizations and agencies, and the public. Our common culture will seek to create an environment where all SAWSC employees have opportunities for professional growth, such as receiving training, attending conferences, and contributing to publications. The SAWSC will encourage the use of new technologies with applicable training, the implementation of mentorship programs, and a safety-first workplace.

\section{Priority Science Topics and Associated Science Goals}

The priority science topics and goals within this plan are organized into five categories: (1) Foundational Data, (2) Effects of Land-Use Change, (3) Coastal Plain Science, (4) Water Availability, and (5) Hazards. The science topics were selected on the basis of relevance to currently understood priority areas of data collection and research in the South Atlantic region. Science goals identify objectives for the SAWSC to work toward completing by the end of 2023. Working groups for each of the priority science topics are tasked with refining strategic actions and identifying annual milestones. As an overarching goal of the five priority science topics, the SAWSC strives to publish science on societally relevant issues and develop innovative ways to display publications through online and electronic media to provide information to policymakers, stakeholders, cooperators, and managers. 


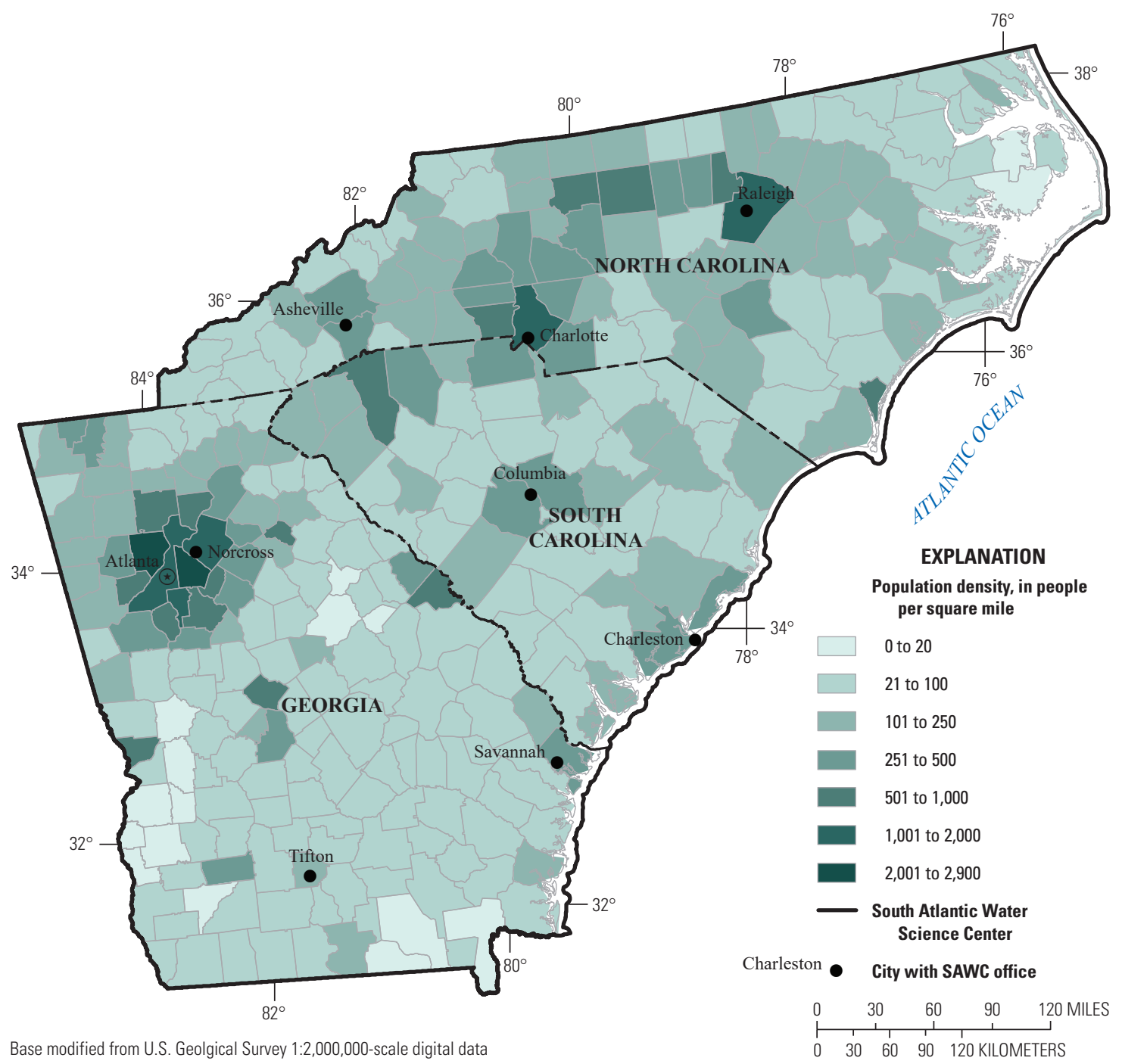

Figure 5. Map showing population density by county in the South Atlantic region (U.S. Census Bureau, 2012).

\section{Topic 1: Foundational Data}

The collection of water-quantity and water-quality data is a core mission of the SAWSC (fig. 6). The SAWSC is committed to providing highly accurate, consistent, and technically defensible data in a timely manner. These data are primarily measurements of surface water, groundwater, precipitation, water quality, and ecological abundance and health. Foundational data collection activities are intended to characterize the quantity and quality of the water resources in the South Atlantic region. Foundational data provide timely decision-making information to State, Federal, and private partners; nongovernmental organizations; and the public. In addition, these data form the framework for much of our interpretive research and assessments.

Uses of foundational data include basic areal hydrologic assessments by Federal and State agencies; flood predictions by the National Weather Service; post-flood analysis by the Federal Emergency Management Agency; reservoir operations by Federal, State, and local agencies to ensure the water quality and biological health of downstream reaches; monitoring of saltwater intrusion and migration to ensure the freshwater integrity at municipal and industrial withdrawal locations; and real-time bridge scour monitoring and evacuation route planning by State Departments of Transportation.

The science goals for the Foundational Data topic are as follows:

1. Maintain the highest quality (precise and accurate) data-collection and processing standards using appropriate USGS protocols. Additionally, the SAWSC plans to investigate improvements to these methods and standards and incorporate improvements into daily operations.

2. Evaluate the relations between the current monitoring network composition (monitoring locations and data types), the science directions of the USGS, and current and future stakeholder needs to ensure that the network distribution is appropriate for addressing the aligned interests. 


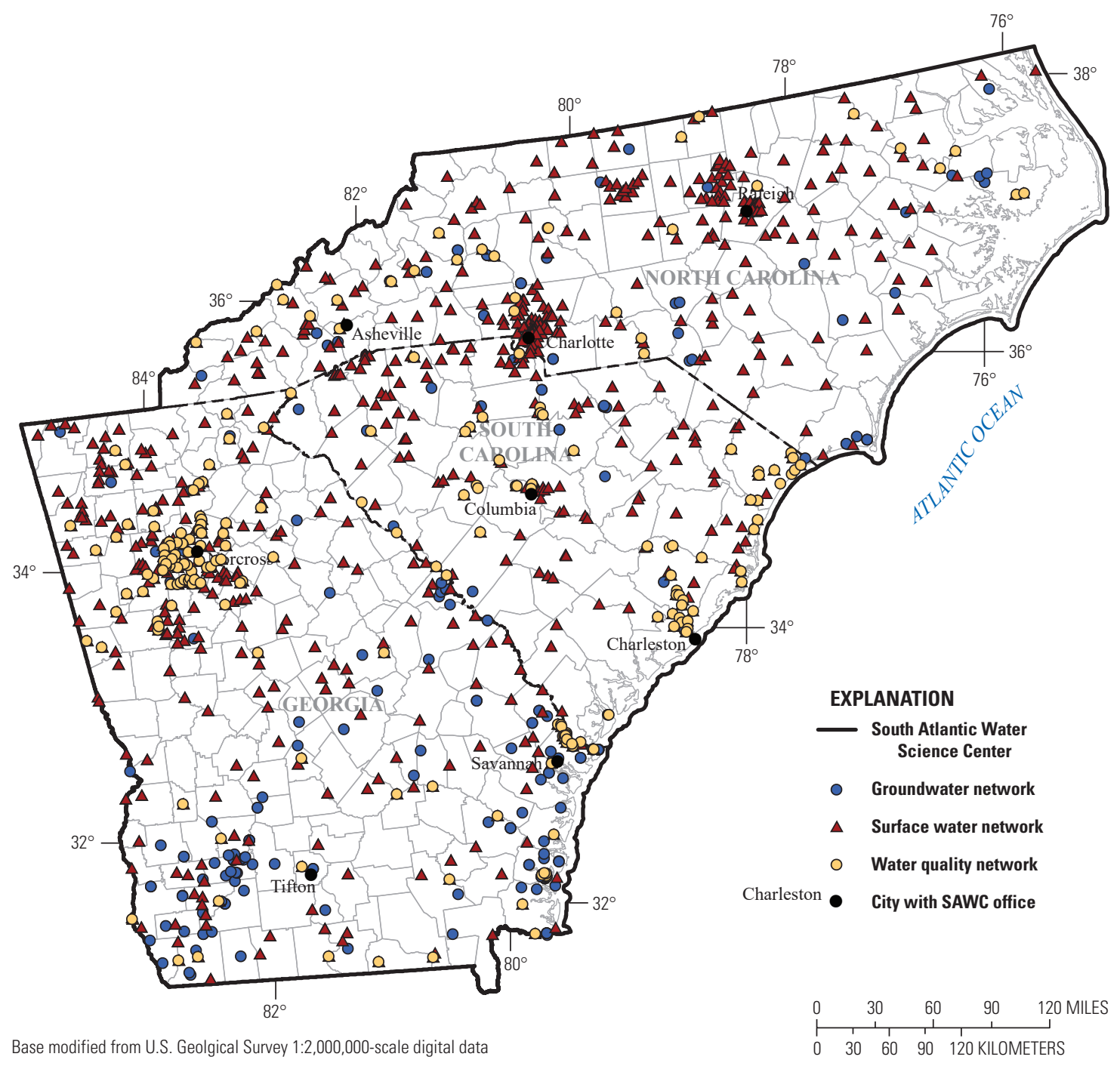

Figure 6. Map showing the South Atlantic Water Science Center's 2017 network of groundwater, surfacewater, and water-quality monitoring sites.

3. Incorporate new, nontraditional (for USGS) foundational data areas (for example, slope stability, dam seepage, erosion potential, hyporheic-zone water quality, microgravity) and investigate other technologies that can be integrated with existing SAWSC monitoring networks to provide additional nontraditional data (for example, fish counts, earthen dam erosion, traffic counts, soil moisture) in real time.

\section{Topic 2: Effects of Land-Use Change}

Changes in land use are altering the quality and quantity of surface water and groundwater, reducing biodiversity, and changing ecological systems (National Research Council, 2001). Natural-resource sustainability relies on an understanding of how the landscape is changing, the drivers of those changes, and how water quantity, water quality, and the ecosystems that depend on water resources are affected by those land-use changes.

The South Atlantic region is home to large, expanding urban centers such as Raleigh, N.C.; Charlotte, N.C.; Columbia, S.C.; and Atlanta, Ga. (figs. 1 and 5). Continued population growth in the South Atlantic region has led to increasing and competing demands on limited water supplies inland and along the coastline. Because of urban expansion, non-urban habitats can become fragmented, affecting ecosystems and the quantity and quality of the water available for use (Niemczynowicz, 1999). In addition, increases in impervious areas owing to urbanization result in flashier stream hydrographs, increase the occurrence of flooding, decrease recharge and base flow, and can accelerate the delivery of contaminants to surface waters. Increasing impervious area is a major concern of many urban hydrology studies. 
Historical and projected land-use distributions and accompanying land-use area percentages for the South Atlantic region are shown in figure 7 and table 1, respectively (Sohl and others, 2014, 2016). During the period 1940-2050, urban land use steadily increases from 1.3 to 10.5 percent. Forest cover increases through the middle of the period (likely owing to forest regrowth on agricultural lands) and then decreases (likely owing to increased urbanization). Cropland decreases from 27.8 to 15.6 percent in the early part of the period and is projected to increase from 2020 through 2050. The extensive agricultural areas in the South Atlantic region are used for crop production, livestock, and confined animal feeding operations. Agricultural activities are predicted to increase in the region as a result of migration from water-deprived agricultural sectors in the Western United States to the more water-rich Southeast following a period evident during the $21^{\text {st }}$ century (fig. 8) (U.S. Department of Agriculture, 2009, 2014). The expected increase in agricultural water use puts further strain on aquifer capacity and base flow for streams and can affect water quality in downstream waterbodies.

In addition to strains on water availability caused by increasing demands from growing populations and agricultural practices, the potential for contamination from energy production and urban development has resulted in concerns about contaminants in surface-water and groundwater systems. The SAWSC is committed to monitoring trends in water quality and the ecological effects of land-use change in the South Atlantic region. Example studies include assessing the effectiveness of phytoremediation of groundwater at an industrial plant in Charleston, S.C., over nearly 20 years (Landmeyer and Effinger, 2016) and evaluating the success of best management practices that use detention ponds to reduce the effects of impervious area on storm runoff and water quality in Gwinnett County, Ga. (Aulenbach and others, 2017). In addition, the SAWSC currently maintains one of the largest urban monitoring programs in the country-in Metropolitan Atlanta - to monitor water availability and quality. The success of these programs should be expanded upon and serve as a model to other parts of the region and the Nation. Innovation in data collection, structured decision-making methodologies, and effective communication to water managers and the public will be critical when documenting sensitivities to landscape change.

The science goals for the Effects of Land-Use Change topic are as follows:

1. Develop seamless and comprehensive datasets to enhance scientific understanding of the spatial and temporal gradients of urbanization, population contraction, agricultural practices, and the effectiveness of mitigation and restoration strategies on surface-water and groundwater quantity, quality, and ecological response in the South Atlantic region.

2. Standardize land-use-based methods for estimating water use across the SAWSC for self-supplied domestic and agricultural uses. Incorporate remote sensing and other types of geospatial information.

3. Develop decision-support assessments and communication tools for partners that describe the response of hydrologic systems to land-use change and the effectiveness of mitigation and restoration strategies. 


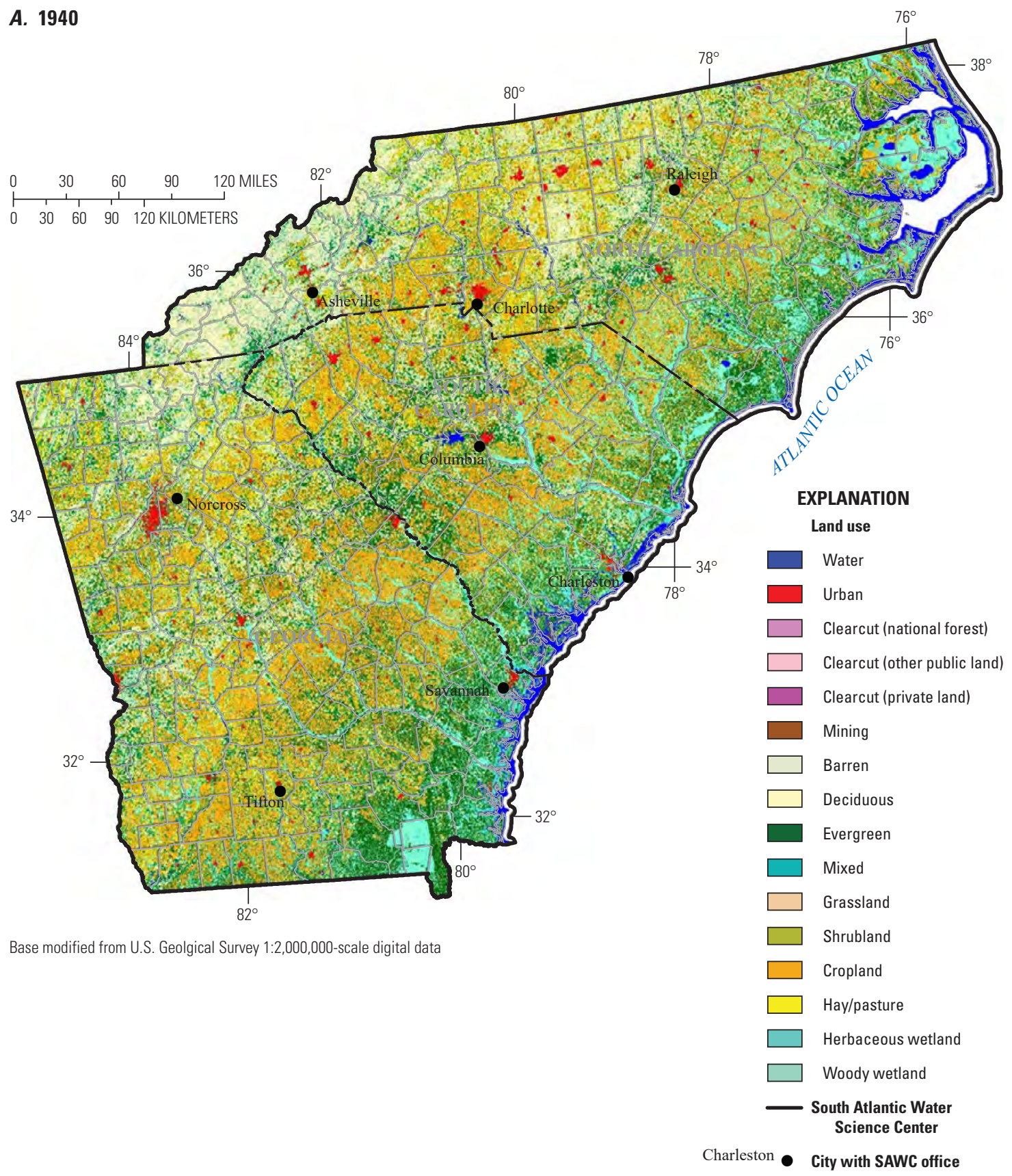

Figure 7. A-E, Maps showing historical and projected land use in the South Atlantic region (Sohl and others, 2014, 2016). 
B. 1970



Figure 7. $A-E$, Maps showing historical and projected land use in the South Atlantic region (Sohl and others, 2014, 2016).-Continued 


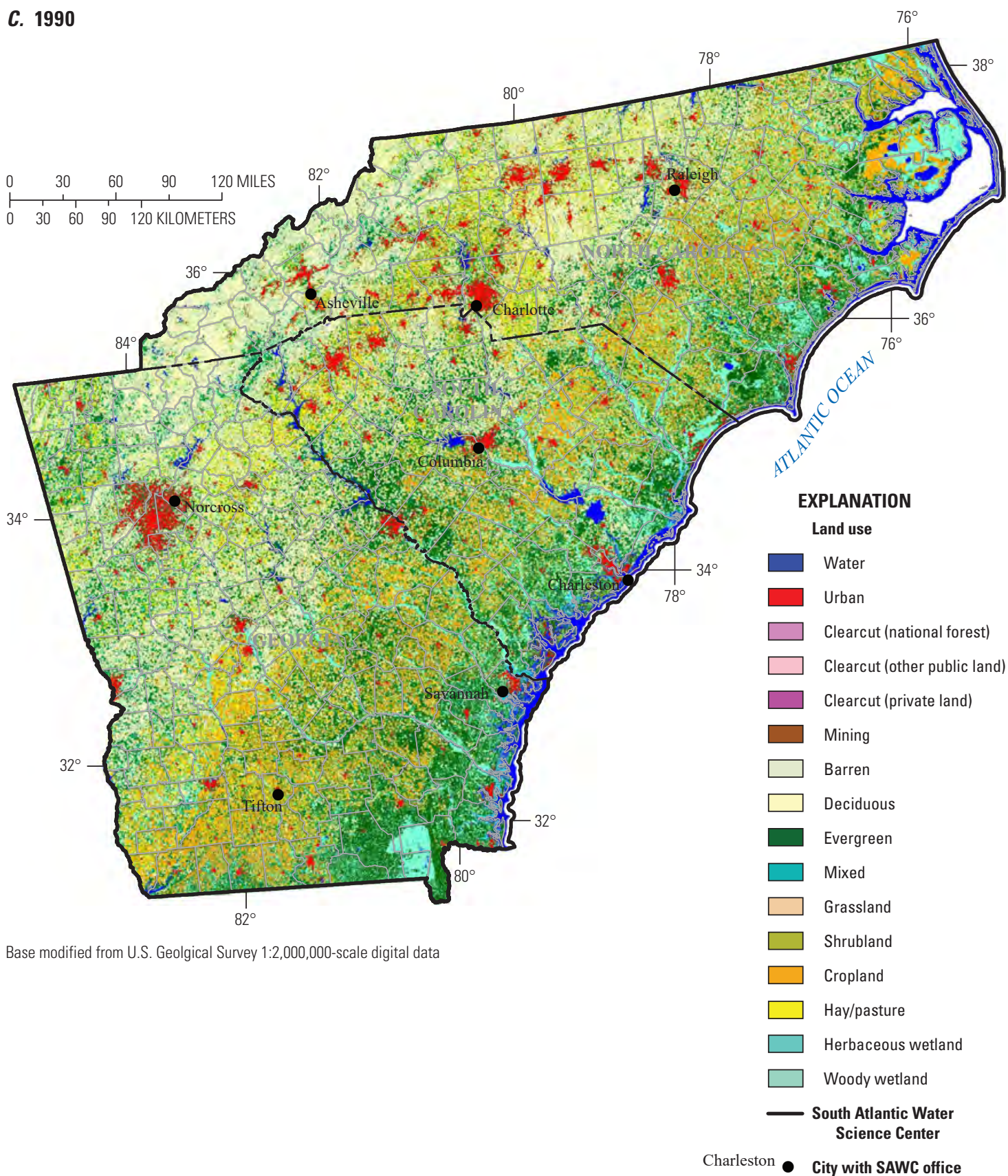

Figure 7. A-E, Maps showing historical and projected land use in the South Atlantic region (Sohl and others, 2014, 2016).-Continued 


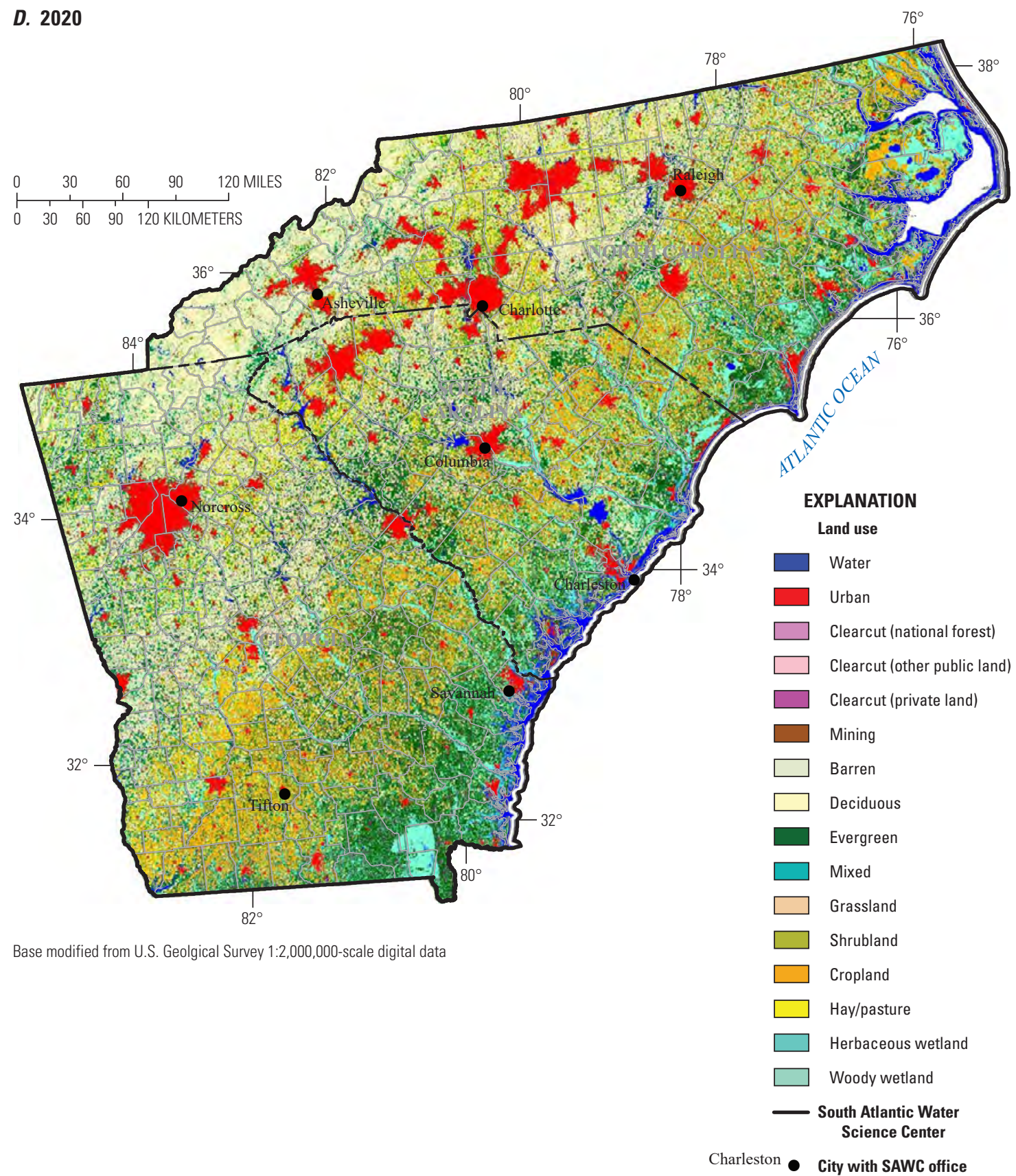

Figure 7. $A-E$, Maps showing historical and projected land use in the South Atlantic region (Sohl and others, 2014, 2016).-Continued 


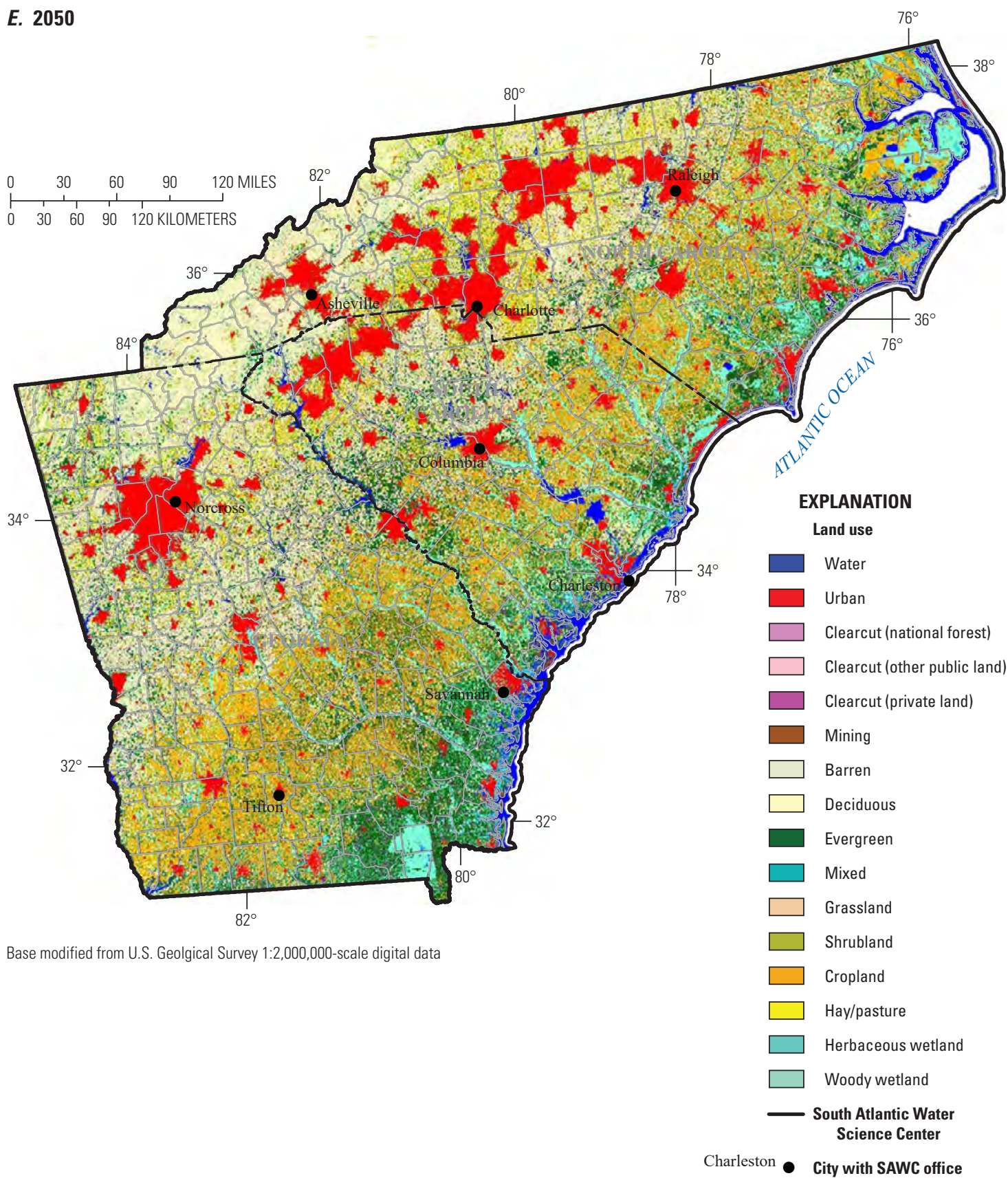

Figure 7. $A-E$, Maps showing historical and projected land use in the South Atlantic region (Sohl and others, 2014, 2016).-Continued 


\section{$\boldsymbol{A}$}

\section{Change in irrigated acreage, 2002-07}

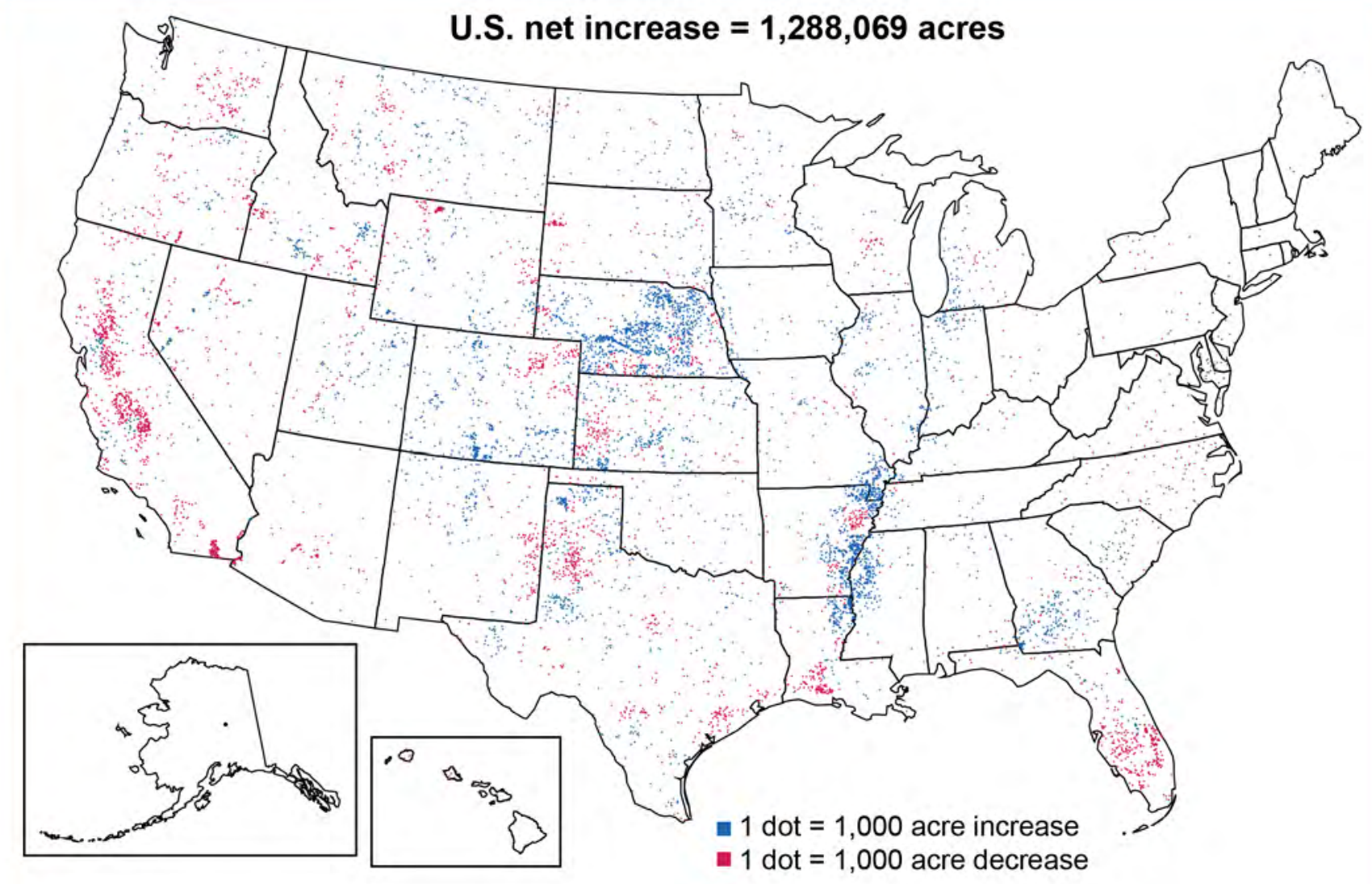

Source: USDA, National Agricultural Statistics Service, Map Atlases for the 2012 Census of Agriculture.

Figure 8. Maps showing the change in irrigated acres from (A) 2002-2007 and (B) 2007-12. Figure from U.S. Department of Agriculture (2018). 
B

\section{Change in irrigated acreage, 2007-12}

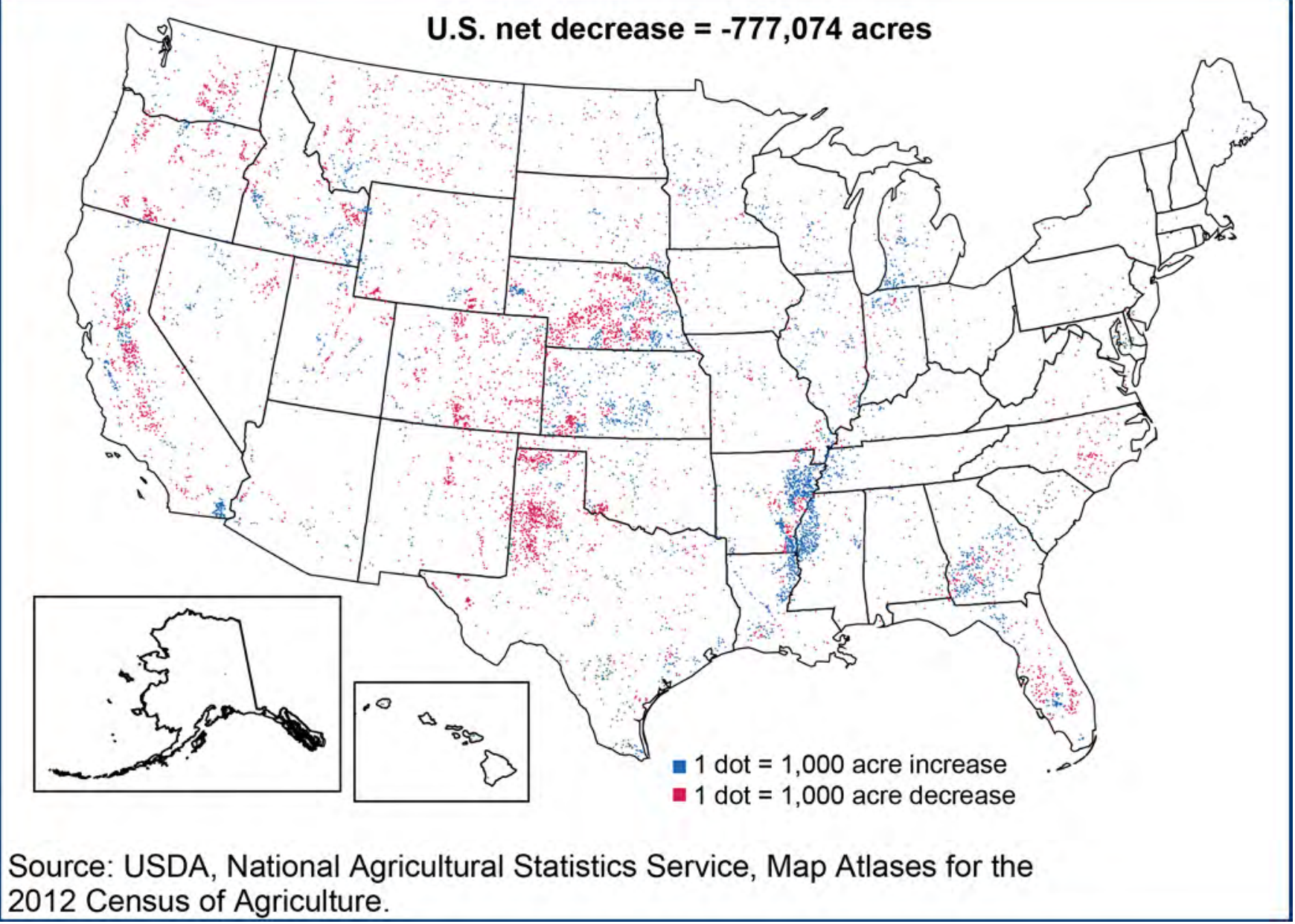

Figure 8. Maps showing the change in irrigated acres from $(A)$ 2002-2007 and $(B)$ 2007-12. Figure from U.S. Department of Agriculture (2018).-Continued

\section{Topic 3: Coastal Plain Science}

The Coastal Plain (fig. 1) contains highly productive and ecologically diverse estuaries and wetlands, as well as shallow to deep aquifer systems that yield large amounts of groundwater. Water resources in the Coastal Plain are subject to diverse and competing interests, including tourism, agriculture, industry, mining, aquaculture, silviculture, recreation, port facilities, and commercial fishing. The Coastal Plain contains high-population-density centers intermixed with low-population rural areas and wildlife refuges, and population growth is projected to continue. Coastal areas of the Southeastern United States, including the South Atlantic region, are experiencing increased seasonal populations of tourists that often place unanticipated stress on local resources.
The Coastal Plain represents a nexus of natural resources and economic opportunity.

Sustainable population growth necessitates stewardship of coastal natural resources through sound data collection, as well as historical and predictive hydrologic and ecological modeling to support informed resource management. Increasing water demands from competing uses can result in migration of the freshwater-saltwater interface in coastal aquifers. For example, we found that removal of fresh groundwater for municipal and industrial demand may result in aquifer salinity rising above levels of potable use (Payne, 2010; McSwain and others, 2014; Cherry and Peck, 2017).

The current and future water capacity for potable use is stressed and in direct competition with the recreational and ecological flow requirements of freshwater resources. 
Vulnerable Coastal Plain hydrologic resources include rivers, lowland streams, wetlands, coastal aquifers, and estuarine ecosystems. To permit the best allocation of freshwater resources and facilitate economically and environmentally sustainable growth in the Coastal Plain, decision-support tools based on defensible data and model simulations are needed by local and State water managers so they can understand the quantity and quality of water supplies and groundwater/ surface-water interactions. In addition, SAWSC scientists need to interact with resource managers about tool development and the possible implications of management decisions on various interests and provide education about data availability and scientific investigations.

Coastal flood plains are at risk of flooding from extreme precipitation events such as tropical cyclones. The effects of additional stressors, such as sea-level rise and drought, on these ecosystems have not been fully assessed. The hydrologic and topographic characteristics of coastal flood plains make them susceptible to both long- and short-term hazards. Modest changes in elevation result in frequent flooding and make coastal areas more susceptible to changes in sea level that can affect the rate and spatial extent of coastal erosion. Droughts in any portion of a watershed affect coastal areas because of their downstream position in the basin and can result in insufficient amounts of freshwater delivered to estuaries that are necessary for aquatic ecosystems.

The science goals for the Coastal Plain Science topic are as follows:

1. Monitor, research, and assess the effects of coastal hazards in the Coastal Plain (for example, inland flooding, tropical event-based flooding, saltwater intrusion, sealevel rise, land subsidence) to quantify the vulnerability of the Coastal Plain to changes in the frequency and magnitude of these hazards.

2. Develop an interdisciplinary analysis of existing information and new research (for example, decision-support tools) that integrates hydrological, geological, biogeochemical, and ecological components of coastal systems.

3. Incorporate the use of nontraditional hydrologic datasets and remotely sensed products for challenging environmental problems in the Coastal Plain such as ecological health, salinity changes, sea-level rise, groundwater/ surface-water interactions, and water-use estimation.

\section{Topic 4: Water Availability}

Water availability is defined in this document as the amount of surface water or groundwater that can be used while maintaining quantities necessary to meet current and future human and ecological demands (fig. 9). Surface water and groundwater in the South Atlantic region are common natural resources under riparian water rights and therefore are considered nonexclusive natural resources. The SAWSC can provide unbiased and independent data on water availability to stakeholders with different and, perhaps, conflicting economic interests in water availability.

Although the South Atlantic region has historically been characterized by abundant precipitation (approximately 50 inches per year), the water available for use by humans, animals, and ecological and ecosystem processes should be considered a limited resource. This water-resource limitation is perhaps most apparent during times of drought and may become even more apparent as demands for water increase with increasing permanent and seasonal populations, industries, agriculture, and fluctuations in climate. Given the anticipated increases in human water demands and the occurrence of droughts, it is imperative that the SAWSC develop, modify, and apply methodologies to provide resource managers with relevant information regarding water availability for human and ecosystems uses. It is critical to assess water needs for each of these competing demands, which will require comprehensive data on the quantity, quality, restoration, management, and economic value of water throughout the region. To effectively manage Coastal Plain water supplies to meet societal and ecological uses, water-resource managers will need estimates of how potential changes in population, land use, and climate may affect aquifer water levels and the frequency, duration, and magnitude of streamflow and salinity intrusion near water-supply withdrawal locations. The SAWSC will provide impartial information to local, regional, State, and Federal stakeholders to facilitate decision making in waterresource allocations while considering multiple water users in basins that cross demographic and political boundaries. Focus area studies in the Apalachicola-Chattahoochee-Flint River, Cape Fear River, and Pee Dee River Basins, part of the USGS National Water Census (https://water.usgs.gov/watercensus/), are contemporary examples of the SAWSC providing such information.

The science goals for the Water Availability topic are as follows:

1. Develop a South Atlantic region-wide water budget that includes timely estimates of water availability. This action will necessitate further work to quantify all water demands.

2. Evaluate the current and potential future positions of the freshwater/saltwater interfaces in aquifers and coastal rivers.

3. Develop tools for the improved management, investigation, and characterization of groundwater and surfacewater resources across the Piedmont, Blue Ridge, and Valley and Ridge Provinces in the South Atlantic region. 


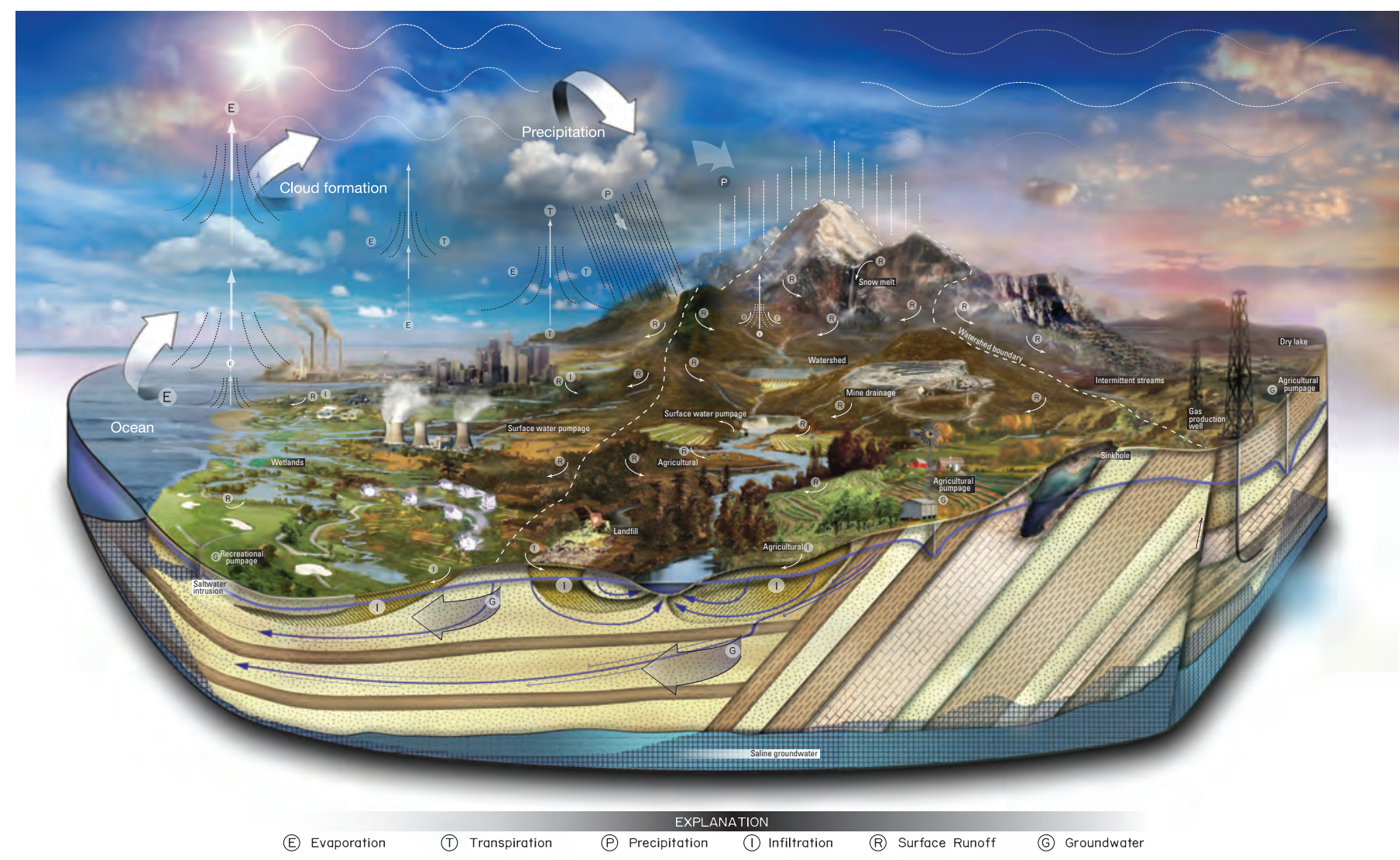

Figure 9. Diagram showing natural and anthropogenic interactions in the hydrologic cycle. Figure from Evenson and others (2013, fig. 8).

\section{Topic 5: Hazards}

Natural and anthropogenic hazards threaten lives, the economy, and ecosystems. Potential hazards in the South Atlantic region include flood inundation caused by inland precipitation and tropical events (fig. 10), drought, point- and nonpoint-source pollution, saltwater intrusion, and to a lesser degree, fire, landslides and earthquakes. Both floods and droughts can also trigger water-quality hazards such as contaminant releases (for example, overland runoff from urban or agricultural lands or sewage spills) or harmful algal blooms (HABs). The SAWSC should respond quickly to these hazards to collect data and disseminate information to stakeholders.

The SAWSC maintains long-term monitoring networks (for example, streamflow, stream-stage, precipitation, waterquality, groundwater-level) for the collection of hydrologic data to characterize hazards. In addition to the long-term monitoring networks, the SAWSC has presurveyed networks, primarily in coastal areas, for the collection of short-term, high spatial and temporal resolution water-level data. The availability of rapid deployment streamgages provides flexibility in obtaining short-term, high-quality hydrologic information at previously ungaged locations (National Hydrologic
Warning Council, 2006). The experience gained from responding to relatively recent large flood events (for example, Metropolitan Atlanta [2009], South Carolina [2015], and Hurricane Matthew [2016]) is a strength of the SAWSC. With regard to drought monitoring, the SAWSC operates a network of wells that are part of the USGS Climate Response Network and has active partnerships with other Federal agencies as part of the National Integrated Drought Information System. The SAWSC has an opportunity to leverage its existing data-collection and interpretation strengths to provide tools and products that are both useful and timely to cooperators and stakeholders. Fostering innovation within the SAWSC is a key component to achieving this objective.

The science goals for the Hazards topic are as follows:

1. Leverage data-collection networks and promote innovative methods of data collection to help in the development of long-range preplanning for potential stakeholder responses.

2. Expand SAWSC's scientific presence in quick-response decision support and continuous monitoring of inland (streams and dams) and coastal flooding and drought events. 


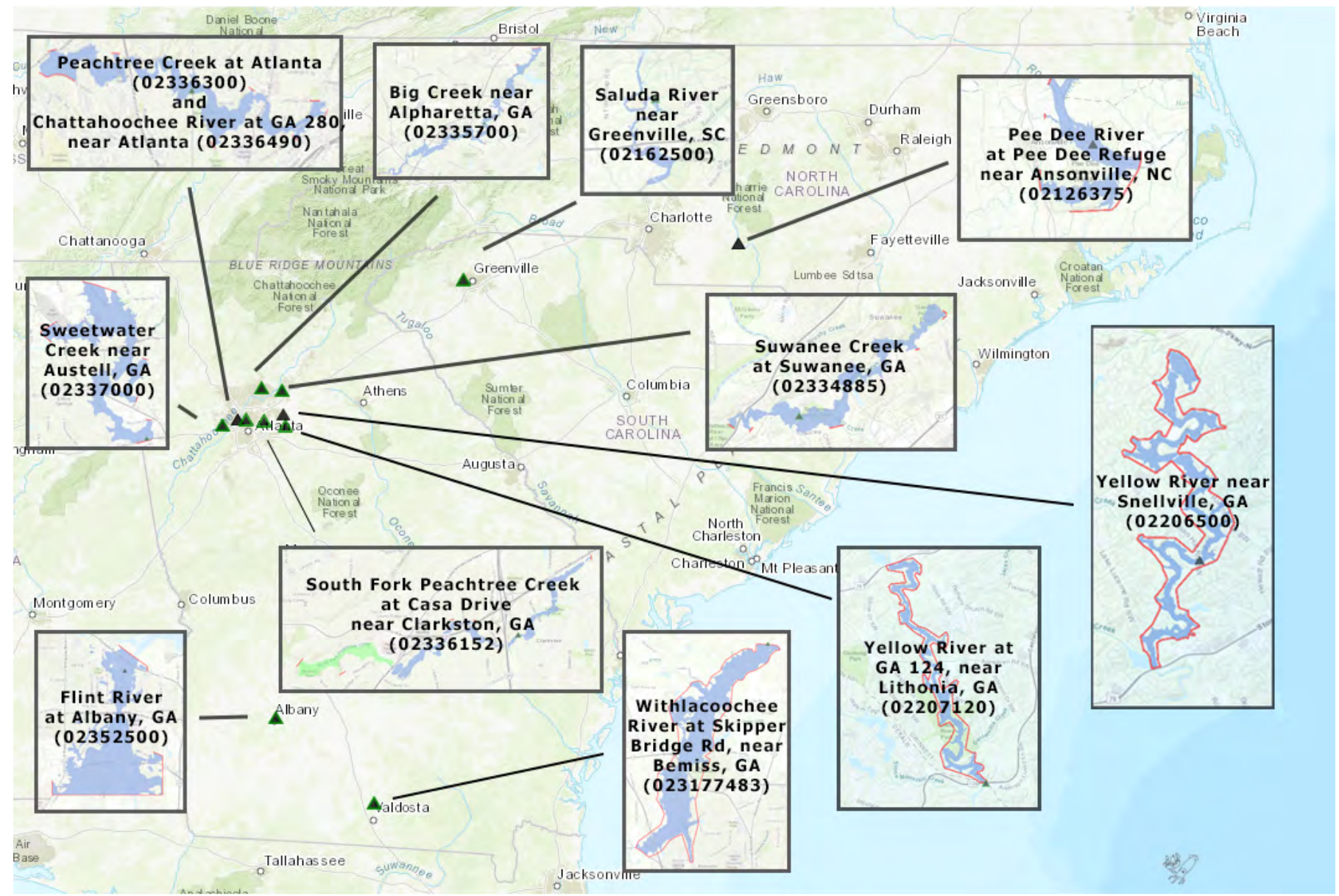

Figure 10. Map showing streamgage sites in the South Atlantic region where the U.S. Geological Survey (USGS) has created flood-inundation maps. Flood-inundation mapping creates a series of maps that help communicate where flooding may occur over a sequential range of river levels. These maps can be connected to real-time and forecasted river levels at USGS streamgages to help communities identify immediate risks during a flood. Figure from U.S. Geological Survey (2017a).

3. Improve and expand communication, including through social media outlets, with cooperators, media, and the public about available data, tools, and products.

4. Investigate the connection between public health threats and the geology and water-quality conditions specific to the South Atlantic region (for example, the connection between high rates of diabetes, kidney disease, and strokes and high concentrations of naturally occurring radium, fluoride, and bromide in groundwater).

\section{References Cited}

Aulenbach, B.T., Landers, M.N., Musser, J.W., and Painter, J.A., 2017, Effects of impervious area and BMP implementation and design on storm runoff and water quality in eight small watersheds: Journal of the American Water Resources Association, v. 53, no. 2, p. 382-399, accessed July 10, 2017, at https://doi.org/10.1111/1752-1688.12501.

Cherry, G.S., and Peck, M.F., 2017, Saltwater intrusion in the Floridan aquifer system near downtown Brunswick, Georgia, 1957-2015: U.S. Geological Survey OpenFile Report 2017-1010, 10 p, accessed July 10, 2017, at https://doi.org/10.3133/ofr20171010. 
Clark, J.M., Journey, C.A., Nagle, D.D., and Lanier, T.H., 2014, Bathymetric maps and water-quality profiles of Table Rock and North Saluda Reservoirs, Greenville County, South Carolina: U.S. Geological Survey Scientific Investigations Map 3289, 2 pls, accessed July 10, 2017, at https://doi.org/10.3133/sim3289.

Conrads, P.A., Journey, C.A., Petkewich, M.D., Lanier, T.H., and Clark, J.M., 2018, Characterization of water quality in Bushy Park Reservoir, South Carolina, 2013-15: U.S. Geological Survey Scientific Investigations Report 2018-5010, 175 p., accessed on March 13, 2019, at https://doi.org/10.3133/sir20185010.

Conrads, P.A., Petkewich, M.D., Falls, W.F., and Lanier, T.H., 2017, Hydrologic characterization of Bushy Park Reservoir, South Carolina, 2013-15: U.S. Geological Survey Scientific Investigations Report 2017-5050, 83 p., accessed on March 13, 2019, at https://doi.org/10.3133/sir20175050.

Evenson, E.J., Orndorff, R.C., Blome, C.D., Böhlke, J.K., Hershberger, P.K., Langenheim, V.E., McCabe, G.J., Morlock, S.E., Reeves, H.W., Verdin, J.P., Weyers, H.S., and Wood, T.M., 2013, U.S. Geological Survey water science strategy - Observing, understanding, predicting, and delivering water science to the Nation: U.S. Geological Survey Circular 1383-G, 49 p., accessed July 10, 2017, at https://doi.org/10.3133/cir1383G.

Feaster, T.D., Weaver, J.C., Gotvald, A.J., and Kolb, K.R., 2018, Preliminary peak stage and streamflow data for selected U.S. Geological Survey streamgaging stations in North and South Carolina for flooding following Hurricane Florence, September 2018: U.S. Geological Survey OpenFile Report 2018-1172, 36 p., accessed on March 13, 2019, at https://doi.org/10.3133/ofr20181172.

Fenneman, N.M., and Johnson, D.W., 1946, Physiographic divisions of the conterminous U.S.: U.S. Geological Survey vector digital data, accessed September 18, 2017, at https://water.usgs.gov/GIS/metadata/usgswrd/XML/ physio.xml\#stdorder.

Jones, L.E., Painter, J.A., LaFontaine, J.H., Sepulveda, N., and Sifuentes, D.F., 2017, Groundwater-flow budget for the lower Apalachicola-Chattahoochee-Flint River Basin in southwestern Georgia and parts of Florida and Alabama, 2008-12: U.S. Geological Survey Scientific Investigations Report 2017-5141, 76 p., accessed September 18, 2018, at https://doi.org/10.3133/sir20175141.

LaFontaine, J.H., Jones, L.E., and Painter, J.A., 2017, Simulations of hydrologic response in the Apalachicola-Chattahoochee-Flint River Basin, Southeastern United States: U.S. Geological Survey Scientific Investigations Report 2017-5133, 112 p., accessed September 18, 2018, at https://doi.org/10.3133/sir20175133.
Landmeyer, J.E., and Effinger, T.N., 2016, Effect of phytoremediation on concentrations of benzene, toluene, naphthalene, and dissolved oxygen in groundwater at a former manufactured gas plant site, Charleston, South Carolina, USA, 1998-2014: Environmental Earth Sciences, v. 75, no. 7, 13 p., accessed July 10, 2017, at https://doi.org/10.1007/ s12665-016-5408-9.

McSwain, K.B., Gurley, L.N., and Antolino, D.J., 2014, Hydrogeology, hydraulic characteristics, and water-quality conditions in the surficial, Castle Hayne and Peedee aquifers of the greater New Hanover County area, North Carolina, 2012-2013: U.S. Geological Survey Scientific Investigations Report 2014-5169, 52 p., accessed July 10, 2017, at https://doi.org/10.3133/sir20145169.

National Hydrologic Warning Council, 2006, Flood management benefits of USGS streamgaging program: Denver, Co., National Hydrologic Warning Council, 37 p., accessed July 11, 2017, at https://water.usgs.gov/osw/pubs/Flood Management_benefits_complete.pdf.

National Oceanic and Atmospheric Administration, [undated], Shoreline mileage of the United States: Silver Spring, Md., National Oceanic and Atmospheric Administration, 2 p., accessed July 12, 2018, at https://coast.noaa.gov/data/docs/ states/shorelines.pdf.

National Research Council, 2001, Grand challenges in environmental sciences: Washington, D.C., The National Academies Press, 106 p., accessed July 10, 2017, at https://doi.org/10.17226/9975.

National Research Council, 2007, River science at the U.S. Geological Survey: Washington, D.C., The National Academies Press, 206 p., accessed July 10, 2017, at https://doi.org/10.17226/11773.

Niemczynowicz, J., 1999, Urban hydrology and water management-Present and future challenges: Urban Water, v. 1, no. 1, p. 1-14, accessed July 10, 2017, at https://doi.org/10.1016/S1462-0758(99)00009-6.

Painter, J.A., Torak, L.J., and Jones, J.W., 2015, Evaluation and comparison of methods to estimate irrigation withdrawal for the National Water Census Focus Area Study of the Apalachicola-Chattahoochee-Flint River Basin in southwestern Georgia: U.S. Geological Survey Scientific Investigations Report 2015-5118, 32 p., accessed July 10, 2017, https://doi.org/10.3133/sir20155118.

Payne, D.F., 2010, Effects of sea-level rise and pumpage elimination on saltwater intrusion in the Hilton Head Island area, South Carolina, 2004-2104: U.S. Geological Survey Scientific Investigations Report 2009-5251, 83 p., accessed July 10, 2017, at https://pubs.usgs.gov/sir/2009/5251/. 
Petkewich, M.D., Journey, C.A., Clark, J.M., Lanier, T.H., Bradley, P.M., and Conrads, P.A., 2018, Hydrodynamic and Water-Quality Monitoring of Bushy Park Reservoir, 20172018: U.S. Geological Survey data release, accessed on March 13, 2019, at https://doi.org/10.5066/P9Z7YOXC.

Sanford, W.E., and Selnick, D.L., 2012, Estimation of evapotranspiration across the conterminous United States using a regression with climate and land-cover data: Journal of the American Water Resources Association, v. 49, no. 1, p. 217-230, accessed July 10, 2017, at https://doi.org/10.1111/ jawr. 12010 .

Sohl, T., Reker, R., Bouchard, M., Sayler, K., Dornbierer, J., Wika, S., Quenzer, R., and Friesz, A., 2016, Modeled historical land use and land cover for the conterminous United States: Journal of Land Use Science, v. 11, no. 4, p. 476-499, accessed July 10, 2017, at https://doi.org/10.1080/ 1747423X.2016.1147619.

Sohl, T.S., Sayler, K.L., Bouchard, M.A., Reker, R.R., Friesz, A.M., Bennett, S.L., Sleeter, B.M., Sleeter, R.R., Wilson, T., Soulard, C., Knuppe, M., and Van Hofwegen, T., 2014, Spatially explicit modeling of 1992-2100 land cover and forest stand age for the conterminous United States: Ecological Applications, v. 24, no. 5, p. 1015-1036, accessed July 10, 2017, at https://doi.org/10.1890/13-1245.1.

Southeast Regional Climate Center, 2017, Monthly and seasonal climate information: Southeast Regional Climate Center web page, accessed July 10, 2017, at https://sercc.com/climateinfo/monthly_seasonal.

Swain, L.A., Mesko, T.O., and Hollyday, E.F., 2004, Summary of the hydrogeology of the Valley and Ridge, Blue Ridge, and Piedmont Physiographic Provinces in the Eastern United States: U.S. Geological Survey Professional Paper 1422-A, 23 p., accessed July 10, 2017, at https://doi.org/10.3133/pp1422A.

Torak, L.J., and Painter, J.A., 2011, Summary of the Georgia Agricultural Water Conservation and Metering Program and evaluation of methods used to collect and analyze irrigation data in the middle and lower Chattahoochee and Flint River Basins, 2004-2010: U.S. Geological Survey Scientific Investigations Report 2011-5126, 25 p., accessed July 10, 2017, at https://doi.org/10.3133/sir20115126.
U.S. Census Bureau, 2012, 2010 census summary file 1: U.S. Census Bureau, [variously paged], accessed September 18, 2018, at https:/www.census.gov/prod/ cen2010/doc/sf1.pdf.

U.S. Department of Agriculture, 2009, Farm and ranch irrigation survey (2008): U.S. Department of Agriculture 2007 Census of Agriculture, v. 3, special studies, part 1, AC-07-SS-1, 209 p., accessed July 10, 2017, at https://www.agcensus.usda.gov/Publications/2007/ Online_Highlights/Ag_Atlas_Maps/Farms/index.php.

U.S. Department of Agriculture, 2014, Farm and ranch irrigation survey (2013): U.S. Department of Agriculture 2012 Census of Agriculture, v. 3, special studies, part 1, AC-12-SS-1, 214 p., accessed July 10, 2017, at https://www.agcensus.usda.gov/Publications/2012/ Online_Resources/Farm_and_Ranch_Irrigation_Survey/.

U.S. Department of Agriculture, 2017, QuickStats: U.S. Department of Agriculture web page, accessed July 10, 2017, at https://quickstats.nass.usda.gov.

U.S. Department of Agriculture, 2018, Irrigation \& water use: U.S. Department of Agriculture web page, accessed September 18, 2018, at https://www.ers.usda.gov/topics/ farm-practices-management/irrigation-water-use/.

U.S. Geological Survey, 2017a, Flood-inundation mapping in Georgia, North and South Carolina: U.S. Geological Survey South Atlantic Water Science Center web page, accessed July 10, 2017, at https://www.usgs.gov/centers/sa-water/ science/flood-inundation-mapping-georgia-north-and-southcarolina?qt-science_center_objects $=0 \#$ qt-science_center_objects.

U.S. Geological Survey, 2017b, National Hydrography Dataset medium resolution: U.S. Geological Survey National Hydrography Dataset, 1:100,000 scale, accessed July 10, 2017, at https://nhd.usgs.gov/NHD_Medium_Resolution.html. 



\section{Appendix 1. Recommended Strategic Actions and Milestones}




\section{Appendix 1. Recommended Strategic Actions and Milestones}

The South Atlantic Water Science Center Strategic Science Plan outlines the priority science topics for the South Atlantic Water Science Center (SAWSC) over the next 5 years and describes goals relevant to each topic. The goals will be used to evaluate the societal relevance of individual projects and to plan for future activities. To accomplish these goals, strategic actions and milestones must be established to fully implement the plan and, ultimately, measure its success. Strategic actions are specific tasks that, if completed, will lead to the accomplishment of goals. Milestones are specific workplan elements that will be assigned target dates by the Priority Science Topic Working Groups for the completion of strategic actions. The Priority Science Topic Working Groups are charged with the creation, definition, and implementation of these critical strategic actions and milestones. The following actions and milestones were compiled during the development of this plan and are provided as a starting point for the Priority Science Topic Working Groups.

\section{Topic 1: Foundational Data}

1. Strategic actions

A. Develop standard metrics and applications for datasets that may require start-up costs but could be somewhat automated in the future (for example, tie flood-inundation maps to real-time data).

B. Analyze the existing foundational data networks to determine if data are collected efficiently and at appropriate (statistically representative) locations by coordinating with SAWSC discipline (groundwater, surface-water, water-quality) specialists.

C. Standardize techniques and methods (field and data processing) across all field offices in the SAWSC.

D. Enhance groundwater networks to increase coverage of all primary aquifers for human and agricultural use and achieve 100 percent real-time coverage for the groundwater networks.

E. Integrate nontraditional sensors at existing monitoring stations and create an outreach product (web page or presentation) to showcase the integration and highlight possible additional capabilities of the core networks.

F. Educate cooperators and stakeholders about datacollection methodologies and the collected data.

2. Milestones
A. Analyze the existing networks (similar to the analysis for Texas described in Slade and others [2001]) and produce geographic information system (GIS) map products of the current networks, areas that need additional monitoring, and results of the network analysis.

B. Develop a database of core information (period of record, quality of records, basin characteristics, land cover, presence of impoundments, substantial water use) for each station in the networks and incorporate the database into the StreamStats application.

C. Provide personnel with training for new technologies to build a workforce with both expertise and flexibility.

D. Install telemetry equipment at 100 percent of the non-real-time groundwater monitoring wells.

E. Install rain gages and soil moisture and meteorological sensors at monitoring network locations where technically feasible, including surface-water and groundwater stations.

F. Enhance coastal monitoring locations with additional sensors for monitoring of coastal storms.

G. Invest in additional sensors at locations where the public comes into frequent contact with water resources, such as popular kayaking or fishing rivers and reservoirs.

H. Find innovative ways to tell the story of hydrologic monitoring with innovative field technologies, such as river cameras, along with easy-to-use web pages and social media posts.

I. Explore the possibility of collaborating with cooperators and stakeholders as part of the process of determining strategic actions and milestones.

J. Continue to explore data coverage for emerging contaminants across the region, both by constituent and spatial/temporal coverage.

\section{Topic 2: Effects of Land-Use Change}

1. Strategic actions

A. Perform a network analysis to determine if existing monitoring networks are adequate to address the effects of landscape changes on water resources in urban areas, agricultural regions, and areas where mitigation or restoration efforts are under- 
way. Identify areas or watersheds where additional monitoring is necessary to quantify the key gradients of urban change or other landscape change in the region (for example, Atlanta, Georgia; Columbia, South Carolina; Charlotte, North Carolina; and Raleigh, North Carolina). Communicate with local and State agencies to ensure monitoring efforts are complementary and not redundant.

B. Develop and maintain mathematical models (for example, SPARROW [SPAtially Referenced Regressions On Watershed attributes]) to establish causeand-effect understanding and forecast the effects of landscape change on water resources, particularly water quality and ecological health.

C. Assess the feasibility of expanding the functionality of SPARROW to include predictions for algae, zooplankton, and additional pollutants or contaminants.

D. Develop in-house expertise for decision-support analysis, including adaptive management techniques, such that the effects of land-use changes on ecosystems can be predicted.

E. Incorporate remotely sensed Earth observation information (for example, Landsat, light detection and ranging [lidar], or National Aeronautics and Space Administration [NASA] imagery and products) into analyses for the characterization of landscape change and associated effects on hydrology (while ensuring that remotely sensed data are at relevant scales). Examples include associating aquifer depletion, streamflow changes, and water quality with land-use and land-cover changes.

F. Develop a consistent set of tools to communicate and disseminate geospatial information on the effects of landscape change to the public and policymakers (for example, the StreamStats application).

G. Examine the long-term hydrologic and water-quality effects of urbanization, agricultural development, and the resulting hydrologic replumbing across the landscape. Examples of replumbing include drainage ditches, underground pipes, and surface-water detention ponds.

2. Milestones

A. Identify consistent objectives and design of the Center's urban hydrology programs to be used for future networks and investigation projects. Identify areas to pursue future monitoring programs and the research necessary for understanding dynamics in urban environment and answering questions on best management practices.
B. Expand projects to incorporate investigations that document the effects of urban land-use change on water quality.

C. Develop a geospatial library with relevant landscape-change spatial datasets for a regional analysis of the effects of land-use change on water resources. Identify missing or inconsistent data for the region and develop a plan to obtain those data through collection or collaboration with the U.S. Geological Survey (USGS) Eastern Geographic Science Center, USGS Earth Resources Observation and Science Center, or other agencies.

D. Engage potential cooperators who might be interested in monitoring and investigating watersheds and aquifers at risk for water-quality issues caused by coal ash effects.

E. Contact State agricultural cooperators to obtain the spatial locations of livestock and aquaculture operations and other crop areas. Use this information to identify potentially affected locations where monitoring is warranted for water-quality and ecological assessments.

F. Engage the regional GIS liaison(s) to discuss spatial dataset needs related to landscape change, lidar, and Landsat.

G. Develop a dataset of restoration and mitigation activities that could be assessed for the effects on water resources and ecology.

H. Develop a web presence highlighting relevant monitoring activities and investigative programs or projects related to this science topic.

I. Propose at least one new study regarding the effects of land-use change each year.

J. Engage Landscape Conservation Cooperatives for collaborative science programs.

K. Develop unmanned aircraft system (UAS) capabilities to contribute to the collection of local, large-scale remotely sensed information needed to monitor and assess landscape change. Develop a list of project ideas that could benefit from remotely sensed information from UAS. (For guidance on the use of UAS, consult U.S. Department of the Interior Operational Procedures Memorandum 11 at https://www.doi.gov/sites/doi.gov/files/uploads/ opm-11.pdf.) 


\section{Topic 3: Coastal Plain Science}

1. Strategic actions

A. Monitor the effects of extreme storm events by developing a continuously monitored, comprehensive, storm-hardened, SAWSC-wide tidal zone monitoring network for water levels. Monitor surface elevation to determine if land is aggrading or subsiding.

B. Evaluate the use of remote sensing as a large-scale measurement tool for ecological health, salinity changes, estuarine function, subsidence, erosion, sea-level rise, submarine groundwater discharge, groundwater/surface-water interaction, and vegetation changes.

C. Develop a long-term water-quality monitoring program in coastal brackish environments to detect spatial and temporal trends in physical properties, nutrients, dissolved oxygen, chlorophyll, and blue-green algae, which can be an integrated measure of best management practices implemented upstream.

D. Couple model scenarios of change in groundwater and surface-water quantity and quality in water-stressed areas of the Coastal Plain to guide future policy decisions.

E. Measure the effects of anthropogenic coastal activities on biogeochemical cycles and production (dissolved inorganic nitrogen and phosphate from sewage, farming, and aquaculture) and their effects on the larger coastal environment (aquatic health and water supply).

F. Develop online products that succinctly summarize targeted scientific areas of interest such as saltwater intrusion (both groundwater and surface water), regional models, floods, and other natural hazards. Additional products could include fact sheets or articles in local coastal science publications that promote the SAWSC or discuss recent SAWSC work in the Coastal Plain.

G. Identify groundwater and (or) surface-water dependent ecosystems and measure community success across a range of hydrologic conditions to determine sensitivity to flow alteration.

H. Install new bench marks to evaluate existing data and assess sea-level rise. This will help facilitate an understanding of how sea-level rise may affect water quality in Coastal Plain aquifers.

2. Milestones

A. Install storm surge brackets in South Carolina and Georgia, survey the brackets, and purchase any additional equipment needed to facilitate quick installations when a hurricane occurs.

B. Identify and focus on two subject areas where remote sensing can most help our current cooperators. Contact the relevant spatial analyst or agency (for example, the local GIS liaison or NASA) for assistance. Select a test area and run scenarios.

C. Identify key areas to install continuous water-quality monitors in the coastal rivers and estuaries of the Coastal Plain.

D. Identify a coastal ecologist within USGS to partner with and (or) partially fund to generate program potential.

E. Create a fact sheet similar to U.S. Geological Survey Fact Sheet 2016-3008 (Lombard, 2016) or Fact Sheet 2016-3064 (Giesen and Givens, 2016) and publish an article on USGS Coastal Plain science in a local State coastal magazine. 


\section{Topic 4: Water Availability}

1. Strategic actions

A. Use existing climate and modeling tools (for example, the Daymet climate dataset as input to the Soil-Water Balance model) to evaluate the adequacy of distribution in the current precipitation network (USGS and other agency data sources). As needed, relocate existing gages or plan strategic locations for new gages. Assess the validity of using volunteercollected precipitation data to address data gaps in regional coverage.

B. Invest in a regional soil-moisture/evapotranspiration (ET) monitoring network.

C. Meet with Federal, State, and local parties interested in fostering partnerships to quantify and manage water resources in the South Atlantic region.

D. Assess regional water losses by evaporation and transpiration as separate processes (one physical and one biological), rather than lumped ET, for further refinement of the water budget. Use remote sensing to quantify irrigation losses and validate with fieldbased data.

E. Apply modeling tools at the regional scale to provide consistent and comprehensive estimates of water availability at gaged and ungaged locations.

F. Evaluate the current water-use accounting methodology to determine ways to better account for use in each category, such as agriculture and domestic demands.

G. Collect data to quantify groundwater recharge in different physiographic provinces with an emphasis on the seasonal distribution and frequency of droughts.

H. Install nested monitoring wells in aquifers located along the Fall Line (fig. 1 in the main text) to determine the extent of hydrologic interaction between Piedmont and Coastal Plain aquifer systems.

I. Install a network of shallow monitoring wells in surficial aquifer systems to assess the water availability and dynamics of these systems.

J. Perform aquifer tests in wells that tap the saltwater interface along coastal areas of the South Atlantic region to quantify the movement of fresh- and saltwater resources.

K. Develop expertise in remote sensing image interpretation and (or) collaborate with key personnel at the USGS Earth Resources Observation and Science Center or the USGS Eastern Geographic Science
Center for improved estimation of water budget components (for example, ET estimates).

L. Couple the geophysical knowledge and tools available to USGS staff with remotely sensed information and in situ information to increase understanding of drought science and prediction (for example, groundwater storage conditions, soil moisture) in the region.

M. Assess factors that affect the water yields of publicsupply and domestic wells in fractured rock aquifers.

N. Investigate the relation of groundwater withdrawals to potential effects on streamflow, especially in upper Coastal Plain aquifers.

O. Evaluate if alterations in streamflow influence stream species and ecosystems.

P. Find ways to study surface-water and groundwater interactions near reservoirs and identify how those interactions affect management decisions.

Q. Work with State health managers to comprehensively investigate the groundwater quality of domestic-supply wells.

R. Develop additional hydrologic modeling expertise in the Center.

S. Improve estimates of streamflow in ungaged streams by obtaining wastewater discharge data from businesses and other institutions.

T. Determine if the scales of spatial products are adequate and appropriate for meeting research and cooperator needs.

U. Assess the need for monitoring water levels and flows at reservoirs where monitoring would be feasible.

V. Quantify variability in water availability caused by potential changes in climate across the South Atlantic region.

2. Milestones

A. Evaluate the existing rain gage network and produce a map of all current and planned gages.

B. Host a multiagency workshop on water availability in areas under pressure to meet water demands for public, domestic, industrial, and agricultural supply.

C. Complete models of streamflow at ungaged locations using the USGS National Hydrologic Model.

D. Develop maps of recharge rates to the outcrop areas of the principal aquifers of the South Atlantic region. 
E. Produce erosivity maps that can be used to document surface-water turbidity associated with changes in land use.

F. Demonstrate the extent of the connection between geology, anomalous groundwater chemistry, and major public health concerns.

\section{Topic 5: Hazards}

1. Strategic actions

A. Investigate technological options to make coastal flooding sensors transmit data for display in real time.

B. Combine State-based Storm-Tide Network web pages into an integrated SAWSC product using spatial information technology.

C. Develop a SAWSC social media presence. Seek to establish SAWSC-specific social media accounts and move approval of social media communication to the SAWSC Director.

D. Synthesize the data-collection strengths of each office of the SAWSC to develop consistency in instrumentation and monitoring across the entire Center, including rapid-response, temporary real-time monitoring.

E. Characterize water-related risks associated with anthropogenic sources in the region, such as eutrophication, harmful algal blooms (HABs), and energy production. Provide the data to decision makers and stakeholders in effective and innovative ways (for example, the Chattahoochee River BacteriAlert program).

F. Develop theoretical methods for effective use of UAS and autonomous underwater vehicles to investigate water-related hazards and to more fully automate data processing for these platforms.

G. Create value-added products from our existing foundational data (for example, "do not drive" maps from flood-inundation data).

H. Develop drought monitoring tools that provide real-time information (for example, water levels, soil moisture profiles, evapotranspiration monitors) to address climatic drought and ecological drought.

I. Develop methods that use technology to monitor salinity, aquifer depletion, and other important groundwater issues and notify decision makers of extreme occurrences.

J. Explore the use of remote sensing technologies and genetics research to identify, characterize, and monitor water-related hazards.

K. Coordinate the use of social media, a staple with the emergency management community, to enhance science communication.

2. Milestones

A. Acquire UAS and appropriately train SAWSC personnel. We recommend there be at least one fully trained person per State.

B. Obtain permission for and create SAWSC-specific social media accounts (for example, Facebook and Twitter). Draft guidance documentation for managing and approving content at the SAWSC level. 


\section{References Cited}

Giesen, J.A., and Givens, C.E., 2016, Science center capabilities to monitor and investigate Michigan's water resources, 2016: U.S. Geological Survey Fact Sheet 2016-3064, 6 p., accessed July 10, 2017, at https://doi.org/10.3133/ fs20163064.

Lombard, P.J., 2016, Flood- and drought-related natural hazards activities of the U.S. Geological Survey in New England: U.S. Geological Survey Fact Sheet 2016-3008, 4 p., accessed July 10, 2017, at https://doi.org/10.3133/ fs 20163008 .
Slade, R.M., Jr., Howard, T., and Anaya, R., 2001, Evaluation of the streamflow-gaging network of Texas and a proposed core network: U.S. Geological Survey Water Resources Investigations Report 01-4155, 40 p., 1 pl., accessed July 10, 2017, at https://doi.org/10.3133/wri014155. 



\section{$\frac{\mathbb{2}}{3}$}

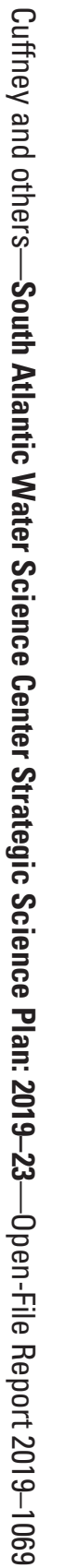

